\title{
The Virus Diseases of Beans
}

\author{
by \\ Patricia J. Klesser \\ Division of Plant Pathology
}

In South Africa several types of bean are cultivated extensively-the runner. bush and haricot types being the most popular. Lima beans are grown on a small scale, but other Phaseolus species are rarely found. Apparently, no natural infections occur in the latter group.

The common bean mosaic has already been reported in this country (9); but, although various other disorders were known to be of virus origin, the causal organisms had not been identified.

Of the viroses described here, only bean mosaic and bean yellow mosaic are well known. The others are apparently new viruses or new variants of existing viruses.

An earnest attempt has been made to correlate these diseases with those already described, but with the information available this has not been possible, in all cases.

The differences in symptom expression may be due to the manifestation of known viruses on other varieties of test plants, or to climatic or environmental factors.

Many plant viruses occur in specific localities, and it is also possible that the diseases described here, are limited to this part of the continent.

A detailed account of each virosis is given here, in the hope that this will enable other workers to place them in the known plant virus classification.

\section{METHODS AND MATERIALS}

Naturally infected plants were collected from many parts of the Union-notably Pretoria and district, Potchefstroom, the Northern Transvaal, Bethal and district and Stellenbosch.

Some sunnhemp plants were sent from Salisbury, Southern Rhodesia.

The standard test plants used were: Phaseolus vulgaris vars. Canadian Wonder and Haricot, Pisum sativum var. Greenfeast, Vicia faba vars. Aquedulce and Long Pod and Vigna unguiculata var. Dr. Saunder's Upright.

Many other legume species were also tested and some solanaceous plants.

Carborundum powder was used to facilitate sap inoculation, and Aphis craccivora was the insect vector in limited experiments.

Although some of the isolates used here came from species other than bean (e.g. sunnhemp and soybean) they are placed with the bean viruses. Some caused symptoms on bean, which closely resembled those of the bean isolates: while others resulted in symptoms on bean which were unusual, whereas on the original host, they were insignificant or similar to those caused by other viruses.

1. BEAN MOSAIC VIRUS Stewart and Reddick.

Physical properties: Thermal inactivation point $56-58 \mathrm{C}$.

Longevity in vitro $1-2$ days.

Dilution end point $1: 1000$. 
Transmission: Mechanical sap inoculation.

Aphis craccivora.

Seed-average of $25 \cdot 3$ per cent for eight varieties.

Host range: Phaseolus acutifolius Gray var. latifolius Freem., P. lunatus L., $P$. vulgaris $\mathbf{L}$.

Occasionally, plants of the following species would show symptoms. These were checked by sub-inoculation to Phaseolus vulgaris. Walp.

Pisum sativum L., Trifolium incarnatum L., Vicia faba L., Vigna unguiculata (L.)

\section{REACTION OF SUSCEPTIBLE SPECIES}

Phaseolus acutifolius.

Local. There are chlorotic spots in seven days.

Systemic. The young leaves develop a veinclearing or chlorotic speckling in 12 days, and they are curled. Later leaves are malformed and mottled with dark green blisters.

$P$. lunatus.

Local. Large chlorotic blotches develop.

Systemic. In three weeks the older leaves show chlorotic vein flecks and the young leaves a chlorotic network.

$P$. vulgaris var. Canadian Wonder.

Local. Usually there is no local reaction, but occasionally inoculated leaves show large chlorotic blotches some time after the young leaves show systemic symptoms, i.e. about three weeks after inoculation.

Systemic. Rarely do the first trifoliates show any symptoms. If so, there are small chlorotic spots. The second trifoliates curl down from the margins (inverse cupping) and are twisted. They may be slightly puckered and have a diffuse dark green mottle. Later formed leaves are lighter green with dark green puckered veinbands. The tips of these leaflets are long and narrow, and may be malformed. The plant is stunted.

Plants grown from infected seed.

Primary leaves have large dark green areas and the leaf surface may be rugose. There is a slight downward curl of the margins. Fig. 1A.

Trifoliate leaves have varying degrees of inverse cupping and twisting, with broad dark green bands along the midrib of older leaves, and dark green mottling of the younger. Fig. 1B. Later formed leaves may show a clearing of the veins or small chlorotic spots. They may also be malformed and elongated. The plants are generally stunted.

The pods of some varieties show no symptoms, but most are mottled with slight depressions on the surface. The variety Rooikrans, if infected early, has pods with sunken red-brown necrotic areas. The virus is readily transmitted from these lesions. var. Haricot.

Local. No reaction.

Systemic. The older leaves are inversely cupped, rolled down or twisted. They have raised dark green areas. Later formed leaves have a dark green mottle or veinbanding and may also be curled down, with narrow tips.

Plants grown from infected seed.

The primary leaves have large irregular chlorotic areas, and the surface is uneven. The margins may be curled down. Fig. 2.

The trifoliate leaves have a dark green veinbanding or mottle with raised areas. The young leaves are slightly smaller than normal and may be tly puckered, and/or malformed. These have small chlorotic areas. The plant is stunted. Fig. 2. 
The following varieties were also tested and found to be susceptible: Black Wonder, Idaho Refugee (Fig. 1D), Kentucky Wonder (Fig. 1E), Long Tom (Fig 1C), Refugee, S.A. Black and White, Tendergreen and Victor.

A survey was made of some experimental plots and the incidence of natural infection can be seen in Table 1.

Pisum sativum.

Local. No reaction.

Systemic. Some plants developed chlorotic veinbands and a mottle similar to those on the bean. On sub-inoculating to bean, typical symptoms were induced.

Trifolium incarnatum.

Local. No reaction.

Systemic. Some leaves show a diffuse veinbanding and they are rolled.

Vicia faba.

Local. No reaction.

Systemic. Some plants develop chlorotic blotches.

Vigna unguiculata.

Local. No reaction.

Systemic. There may be a chlorotic network followed by a diffuse chlorotic mottle on some varieties.

Natural source of virus: Phaseolus vulgaris vars. Canadian Wonder, Kentucky Wonder, Long Tom, Rooikrans and Haricot from Pretoria and district, Nylstroom, Bethal, Rustenburg and Potchefstroom.

\section{IDENTIFICATION.}

From the characteristic symptoms on beans and the amount of seed transmission there can be little doubt that this is the common bean mosaic virus. $(34,42)$.

\section{TABLE 1.-Incidence of Bean Mosaic Virus in Field Plots \\ Roodeplaat-March 1956}

(a) Bush Beans.

\begin{tabular}{|c|c|c|c|}
\hline Name & $\begin{array}{l}\text { Per cent } \\
\text { Natural } \\
\text { Infection }\end{array}$ & Name & $\begin{array}{l}\text { Per cent } \\
\text { Natural } \\
\text { Infection }\end{array}$ \\
\hline Top Crop........... & $2 \cdot 0$ & Breustedts Pallas....... & $75 \cdot 0$ \\
\hline Seminole............ & $4 \cdot 2$ & Long Tom............ & $78 \cdot 3$ \\
\hline Refugee............ & $5 \cdot 0$ & Wachsbone.......... & $91 \cdot 0$ \\
\hline Idaho Refugee......... & $9 \cdot 5$ & Brytböna............ & $98 \cdot 0$ \\
\hline Stamslabonen Voorluk & $12 \cdot 5$ & St. Andreas........... & $98 \cdot 0$ \\
\hline Tendergreen........... & $16 \cdot 3$ & 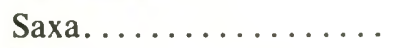 & $99 \cdot 0$ \\
\hline Black Wonder........ & $20 \cdot 2$ & Burpees Stringless...... & $100 \cdot 0$ \\
\hline Victory........... & $38 \cdot 0$ & Grandex............ & $100 \cdot 0$ \\
\hline Streamliner.......... & $42 \cdot 4$ & Heinrichs Riesen...... & $100 \cdot 0$ \\
\hline Black Wax Pod...... & $50 \cdot 0$ & Kaiser Wilhelm....... & $100 \cdot 0$ \\
\hline Wach's Express....... & $57 \cdot 0$ & Double White......... & $100 \cdot 0$ \\
\hline Canadian Wonder..... & $57 \cdot 0$ & Double Princess........ & $100 \cdot 0$ \\
\hline Nordstern............ & $69 \cdot 0$ & Double Holland Princess & $100 \cdot 0$ \\
\hline Wach's Breustedts..... & $70 \cdot 0$ & & \\
\hline
\end{tabular}


(b) Runner Beans.

As the runners were tangled on the trellises it was impossible to count the individual plants, so the percentage is only approximate.

\begin{tabular}{|c|c|c|c|}
\hline Name & $\begin{array}{l}\text { Per cent } \\
\text { Natural } \\
\text { Infection }\end{array}$ & Name & $\begin{array}{l}\text { Per cent } \\
\text { Natural } \\
\text { Infection }\end{array}$ \\
\hline Canfreezer.......... & $0 \cdot 0$ & Gellman Runner...... & $100 \cdot 0$ \\
\hline Green Savage........ & $5 \cdot 0$ & Wach's Goldbone...... & $100 \cdot 0$ \\
\hline Everbearing. ........ & $5 \cdot 0$ & Mittelfrühe........... & $100 \cdot 0$ \\
\hline Kentucky Wonder..... & $20 \cdot 0$ & Phenomenon.......... & $100 \cdot 0$ \\
\hline Abundance.......... & $30 \cdot 0$ & Meisterstück......... & $100 \cdot 0$ \\
\hline Kapitan Weddingen.... & $80 \cdot 0$ & Lazy Housewife....... & $100 \cdot 0$ \\
\hline
\end{tabular}

\section{2.-BEAN MOSAIC VIRUS STRAIN}

A second seed-borne virus was found on Phaseolus vulgaris var. Canadian Wonder which is used extensively in the insect proof glasshouses. In several batches of seed, about 12 per cent of the seedlings showed symptoms on the primary leaves immediately on unfolding. Conspicuous symptoms later developed on the trifoliate leaves. Fig. 3A.

The effect simulates a heritable abnormality, but positive sub-inoculations to many plant species disprove this possibility.

Physical properties: Thermal inactivation point $60-62^{\circ} \mathrm{C}$.

Longevity in vitro $2-3$ days.

Dilution end point 1:1000-1:5000.

Transmission: Mechanical sap inoculation.

Seed-borne approx. 12 per cent.

Not by Aphis craccivora.

Host range: Arachis hypogaea L., Crotalaria juncea L., C. spectabilis Roth., Dolichos lablab L., Glycine max (L.) Merr., Lathyrus odoratus L., Lupinus albus L., vars. sweet and bitter, L. luteus L., L. mutabilis Sweet., Medicago lupulina L., M. sativa L., Melilotus officinalis Willd., Phaseolus acutifolius Gray var. latifolius Freem., $P$. lunatus L.. P. mungo L., P. vulgaris L., Pisum sativum L., Trifolium hybridum L., $T$. incarnatum L., $T$. pratense L., $T$. repens L., Vicia faba L., Vigna sesquipedalis (L.) Wight., V. unguiculata (L.) Walp., Voandzeia subterranea Thouars.

\section{REACTION OF SUSCEPTIBLE SPECIES}

Arachis hypogaea.

Local. No reaction.

Systemic. After 14 days there are chlorotic spots on the young leaves. Later ones are chlorotic with dark green islands.

Crotalaria juncea.

Local. No reaction.

Systemic. There are chlorotic spots in 10 days and later leaves are mottled and slightly puckered.

C. spectabilis.

Local. No reaction.

Systemic. The young leaves develop a veinclearing. and chlorotic spotting. and flecking. Later leaves are mottled with dark green veinbands, and they are crinkled. Dolichos lablab.

A symptomless carrier. 


\section{Glycine max.}

Local. Chlorotic stars develop in five days.

Systemic. The trifoliates have isolated yellow areas which may cause a malformation.

Lathyrus odoratus.

Local. No reaction.

Systemic. A chlorotic spot mottling develops on most leaves.

Lupinus albus var. sweet.

Local. Necrotic specks develop.

Systemic. The young leaves remain folded and have a chlorotic network. Later leaves develop a mosaic and have wavy margins.

L. albus var. bitter.

Local. No reaction.

Systemic. Most leaves are chlorotic with dark green blisters. They are small and curled. The plant is rosetted.

L. luteus.

Local. No reaction.

Systemic. The leaves are mottled, elongated and malformed.

L. Mutabilis.

Local. No reaction.

Systemic. The leaves are chlorotic with dark green blisters and necrotic specks. They are small and stringlike and the plant is rosetted.

Medicago lupulina.

Local. No reaction.

Systemic. After an initial spotting, later leaves develop a chlorotic streak mottle. M. sativa.

Local. No reaction.

Systemic. There may be diffuse chlorotic spots.

Melilotus officinalis.

Local. No reaction.

Systemic. There are chlorotic streaks leaving dark green veinbands. The leaves are slightly puckered.

Phaseolus acutifolius.

Local. Chlorotic spots develop which later become necrotic.

Systemic. There is a chlorotic mottle with dark green blisters which result in an uneven leaf surface.

$P$. lunatus.

Local. There are chlorotic spots in five days.

Systemic. Most leaves develop chlorotic vein flecks with occasional chlorotic spots. P. mungo.

Local. Chlorotic spots develop in five days.

Systemic. The young leaves have chlorotic specks.

$P$. vulgaris var. Canadian Wonder.

Local. There may be isolated chlorotic specks in five days.

Systemic. The young leaves are malformed and curl to one side. They develop an irregular chlorotic speck mottle or vein flecking. Some plants are stunted. Fig. 3B. var. Haricot.

Local. Small chlorotic spots may develop in five days.

Systemic. The leaves are crinkled, curled and malformed. They develop a chlorotic speck mottle.

Pisum sativum.

Local. No reaction.

Systemic. The young leaves develop a veinclearing and chlorotic spotting in 10 days. Later leaves are mottled, and the plant is rosetted. 
Trifolium hybridum.

Local. No reaction.

Systemic. A chlorotic streaking develops.

T. incarnatum.

Local. No reaction.

Systemic. The young leaves show a chlorotic network. Later leaves are chlorotic with dark green areas and also crinkled. The plant is stunted and rosetted.

T. pratense.

Local. No reaction.

Systemic. There is a chlorotic mottle leaving a dark green band along the midrib.

T. repens.

A symptomless carrier.

Vicia faba.

Local. Necrotic lesions develop, and the rest of the leaf becomes chlorotic.

Systemic. No reaction.

Vigna sesquipedalis.

Local. Chlorotic spots develop in five days.

Systemic. After a veinclearing there is a chlorotic spot mottle.

V. unguiculata.

Local. There are chlorotic spots in five days.

Systemic. The young leaves develop a chlorotic network and later ones a chlorotic spotting.

Voandzeia subterranea.

Local. No reaction.

Systemic. After a chlorotic flecking on the young leaves, later ones develop mottle with necrotic specks.

Natural source of virus: Phaseolus vulgaris.

Canadian Wonder plants sown in an insect-free glasshouse. The primary leaves had chlorotic, almost white, specks, uniformly scattered over the leaf surface. The trifoliates were crinkled, slightly malformed and often curved to one side. There were areas of chlorotic speck mottling with varying amounts of necrosis in the chlorosis. The plants were severely stunted. Fig. $3 \mathrm{~A}$.

\section{IDENTIFICATION.}

The symptoms caused by this virus on bean seem to resemble those described by Horsfall $(17,18)$ in a brief report on the one-sided mosaic-a strain of common bean mosaic virus. However, Zaumeyer (51) working with a disorder similar to that found by Horsfall, attributed the symptom to a heritable abnormality.

When sap from the bean plants used in the experiments described here, was mechanically inoculated to several other legumes, obvious virus symptoms developed. Thus, it was concluded that in this case there was an infective organism involved and not a genetical mutation. Further tests proved that a virus was present.

Bean mosaic virus and its strains are known to be easily seed-transmissible, but there are also reports of the possible seed transmission of the red node virus. Thomas and Graham (46) and bean Southern mosaic virus, Zaumeyer (55). Neither of the latter two viruses show further similarities with the one described here.

The type bean mosaic virus and most of its strains have very restricted host ranges, whereas with this virus, 26 species of Leguminosae are susceptible. 
Snow (41) reported that a strain from gladiolus, which was 100 per cent seed-borne in beans, was able to infect several other legumes; but not broad bean, red, white or sweet clovers-all of which are hosts to this virus.

As this virus is also seed-transmissible it is provisionally placed with the bean mosaic virus group.

\section{3.-BEAN CHLOROTIC RINGSPOT VIRUSES}

Although none of these viruses originated from naturally infected Phaseolus vulgaris. the symptom expression on the bean is common to all forms described here. The local reaction consists of unusual, very marked chlorotic ring and line, or ringspot patterns, and the systemic symptom includes a mosaic and dark green blistering accompanied by a necrotic speckling.

The four isolates described here differ from one another on other host plants, but they are provisionally grouped together as strains of one virus, as their reactions on bean are identical.

Natural source of virus and locality:

Strain A.-Crotalaria juncea. Pretoria district and Groblersdal.

Strain B.--Glycine max. Pretoria and Bethal districts and Potchefstroom.

Strain C.-Voandzeia subterranea. Pretoria and district.

Strain D.-Erythrina caffra. Pretoria.

\section{PhySICAL PROPERTIES}

\begin{tabular}{|c|c|c|c|}
\hline & $\begin{array}{l}\text { Thermal } \\
\text { inactivation } \\
\text { point C. }\end{array}$ & $\begin{array}{l}\text { Longevity in } \\
\text { vitro days. }\end{array}$ & Dilution end point. \\
\hline 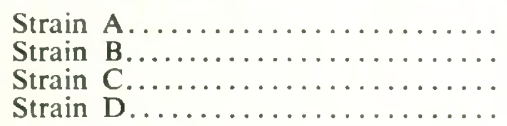 & $\begin{array}{l}58-60 \\
56-58 \\
56-58 \\
60-62\end{array}$ & $\begin{array}{l}2-4 \\
2-3 \\
\mathrm{I}-2 \\
1-2\end{array}$ & $\begin{array}{r}1: 5000-1: 10000 \\
1: 1000-1: 2000 \\
1: 2000-1: 5000 \\
1: 1000-1: 2000\end{array}$ \\
\hline
\end{tabular}

Transmission: All are transmissible by mechanical sap inoculation. Aphis craccivora is not a vector.

Symptoms on naturally infected plants:

Strain A.-Crotalaria juncea. Most leaves had a mosaic mottle with dark green veinbands. They were also malformed and rolled. The older leaves had necrotic specks.

Strain B.-Glycine max. There were chlorotic specks, spots, veinbands or a mottle on the leaves, and they were slightly malformed and crinkled. The plants were rosetted and stunted.

Strain C.-Voandzeia subterranea. The leaves had a chlorotic mottle and the plants were rosetted.

Strain D.-Erythrina caffra. The young leaves were reduced in size and had chlorotic spots. Older leaves showed a chlorotic, almost yellow, mottle. 


\section{HOST RANGES}

\begin{tabular}{|c|c|c|c|c|}
\hline \multirow{2}{*}{ Host Plant. } & \multicolumn{4}{|c|}{ Strains. } \\
\hline & A & B & C & D \\
\hline 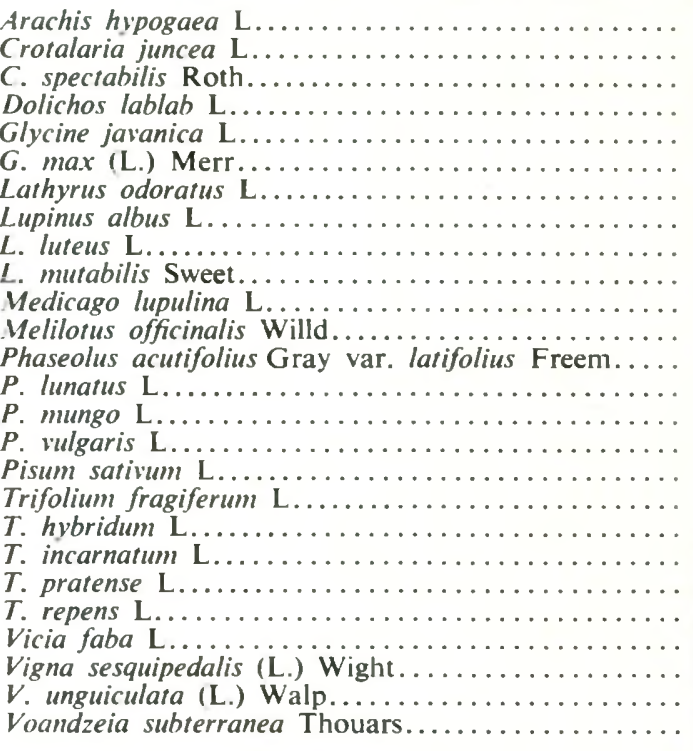 & $\begin{array}{l}+ \\
+ \\
+ \\
+ \\
+ \\
+ \\
+ \\
+ \\
+ \\
+ \\
+ \\
+ \\
+ \\
+ \\
+ \\
+ \\
+ \\
+ \\
+ \\
+ \\
+\end{array}$ & $\begin{array}{l}+ \\
+ \\
+ \\
+ \\
+ \\
+ \\
+ \\
+ \\
+ \\
+ \\
+ \\
+ \\
+ \\
+ \\
+ \\
+ \\
+ \\
+ \\
+ \\
+ \\
+ \\
+\end{array}$ & $\begin{array}{l}+ \\
+ \\
+ \\
+ \\
+ \\
+ \\
+ \\
+ \\
+ \\
+ \\
+ \\
+ \\
+ \\
+ \\
+ \\
+ \\
+ \\
+ \\
+ \\
+ \\
+ \\
+ \\
+ \\
+ \\
+\end{array}$ & $\begin{array}{l}+ \\
+ \\
+ \\
+ \\
+ \\
+ \\
+ \\
+ \\
+ \\
+ \\
+ \\
+ \\
+ \\
+ \\
+ \\
+ \\
+ \\
+ \\
+ \\
+ \\
+ \\
+ \\
+ \\
+ \\
+\end{array}$ \\
\hline
\end{tabular}

\section{REACTION OF SUSCEPTIBLE SPECIES}

Not all host plants were inoculated with all four strains, but available results are tabulated below. The letters $\mathrm{A}-\mathrm{D}$ indicate the strains used.

Arachis hypogaea. B.C.

Local. B.C. No reaction.

Systemic. B.C. The leaves are chlorotic with dark green islands or veinbands Crotalaria juncea. A-D.

Local. B. There are chlorotic spots in 10 days.

C.D. Necrotic spots or rings develop.

A. A combination of the above, viz., chlorotic spots which later become necrotic.

Systemic. A. After a chlorotic spotting of the young leaves later ones are mottled with dark green blisters. They are also malformed and almost stringlike. The old leaves have necrotic specks. The plant is stunted.

C. There is less malformation than with A but more necrosis-some plants may collapse.

B. D. There is a veinclearing and chlorotic spotting followed by a mottle with dark green veinbands or concentric chlorotic patterns. Fig. 5A. With D the leaves have wavy margins and may be slightly malformed.

C. spectabilis. A-D.

Local. A. D. No reaction.

B. C. There are isolated necrotic lesions. 
Systemic. All show a veinclearing followed by a mottle with dark green islands, veinbands or blisters. Fig. 5B. With $\mathrm{A}-\mathrm{C}$ the leaves are also crinkled and rolled; and the plant is rosetted with $\mathrm{A}$.

Dolichos lablab. A. C. D.

A symptomless carrier for the three strains.

Glycine javanica. A.

Local. There are chlorotic spots in six days.

Systemic. A diffuse chlorotic spotting develops.

G. max. A-D.

Local. C. No reaction.

A. B. There are chlorotic specks or ring and line patterns.

D. A slight veinal necrosis develops.

Systemic. C. D. The leaves have chlorotic patterns and irregular dark green areas. They are also crinkled. Fig. $5 \mathrm{H}$.

A. B. In addition there are necrotic specks, Fig. 5I, and with $\mathbf{A}$ the plant is stunted and rosetted.

Lathyrus odoratus. A. C. D.

Local. None show a reaction.

Systemic. A. D. The leaves are mottled with daik z.een veınbancs, and rolled or cupped.

C. There are chlorotic streaks along the veins and the leaves are malformed.

Lupinus albus. A-D.

Local. C. No reaction.

D. There are first chlorotic spots, but later the leaves are uniformly chlorotic.

A. There are chlorotic spots which later become necrotic and the leaves drop.

B. The chlorotic spots have a necrotic speck in the centre.

Systemic. D. The leaves develop a mosaic and the plant is slightly stunted.

B. C. As well as a mosaic. the leaves have dark green blisters and they are small and malformed. With B many leaves drop, leaving an almost bare stem and petioles.

A. In addition there are necrotic specks on the leaves and the plant is severely stunted.

L. luteus. A-D.

Local. C. D. No reaction.

A. B. Chlorotic spots develop.

Systemic. C. D. The young leaves remain folded and have wavy margins. Later formed leaves are mottled, and malformed or elongated. The plant is stunted.

A. B. In addition there are necrotic specks.

L. mutabilis. A. B. D.

Local. No reaction.

Systemic. With all three strains the leaves are mottled, malformed and reduced in size. The plant is rosetted.

Medicago lupulina. A. C. D.

Local. No reaction.

Systemic. A. C. After a veinclearing there is a mottle with chlorotic streaks. The leaves are crinkled.

D. A symptomless carrier.

Melilotus officinalis. A-D.

Local. A-C. No reaction.

D. There are chlorotic spots.

Systemic. B-D. The leaves are mottled and crinkled.

A. There is a chlorotic ring spotting on the young leaves, and streaking on later ones, which are also small and malformed. Fig. 5F.

Phaseolus acutifolius. A-D.

Local. A. Chlorotic spots and veins develop. 
B. C. D. There are necrotic lesions and veins plus chlorotic spots. These leaves usually collapse.

With C. there is also a marked epinasty.

Systemic. A. The young leaves curl back and have chlorotic veins and spots. Later leaves have an almost white speck mottling.

C. In addition to the above mottle there are dark green blisters. The pods are also mottled.

B. C. D. The young leaves curl back and develop a chlorotic network or patterns which become necrotic. Fig. 5D. This results in a collapse of plants inoculated with D. Should secondary shoots develop they have malformed. mottled leaves.

$P$. lunatus. A-D.

Local. D. No reaction.

B. Large chlorotic blotches develop.

A. C. There are chlorotic spots or ringspots which with C. become necrotic later. Fig. 5E.

Systemic. With all strains there is a chlorotic network or vein flecking. With $\mathrm{A}$ and $\mathrm{D}$ this is accompanied by a necrosis in the chlorosis.

P. mungo. A-D.

Local. C. No reaction.

D. Chlorotic spots develop.

A. B. There are necrotic spots and veins.

Systemic. A-C. There is a chlorotic spotting.

D. Only a diffuse mottle develops.

P. vulgaris. A-D.

(a) var. Canadian Wonder.

Local. All induce chlorotic ringspots, ring and line patterns or a vein etching. Fig. 4A.

Systemic. The young leaves develop a veinclearing and chlorotic spots, Fig. 4D., and the leaves curl down. On some newly formed leaves there are yellow specks or distinct rings Fig. 4E., but later there is a mottle. The leaves are crinkled and have many small necrotic specks. Fig. 4C.

With $\mathrm{D}$. the pods are mottled and with $\mathrm{C}$. they are malformed and have necrotic rings. Fig. 5G.

(b) var. Haricot.

Local. All strains result in chlorotic ringspots, or ring and line patterns. Fig. 4B.

Systemic. After an initial veinclearing and chlorotic spotting the next formed leaves are mottled with dark green blisters, and they are malformed. The plants are rosetted.

With A. there is also a necrotic speckling which may cause a collapse of the plant.

(c) vars. Black Wonder, S.A. Black and White, Long Tom and Victor develop symptoms similar to Canadian Wonder.

(d) vars. Tendergreen and Idaho Refugee do not produce a distinct local

reaction. but the systemic symptoms are similar to those on Canadian Wonder. Pisum sativum. A-D.

Local. B. C. No reaction.

A. Chlorotic specks develop and the leaves drop.

Systemic. B. C. Some leaves are mottled, while others have chlorotic areas which lead to a constriction of the laminae. The plants are rosetted and stunted.

A. The young leaves remain folded and have a chlorotic network and spotting. Later formed leaves develop a mosaic, while the old leaves have a white vein etching. The plant is rosetted and the tendrils are abnormally curled.

D. A symptomless carrier.

Trifolium hybridum. A. B. D.

Local. No reaction. 
Systemic. All three strains cause chlorotic spots or streaks and occasionally a mottle.

A. can be latent on this host.

$T$. incarnatum. A-D.

Local. A. B. C. No reaction.

D. There is a chlorotic vein etching and spotting.

Systemic. A. B. C. After a veinclearing there is a mottle with dark green veinbands, and the leaves are crinkled.

D. In addition the older leaves develop chlorotic spots with necrotic rings.

T. pratense. A-D.

Local. No reaction.

Systemic. B. C. D. There are chlorotic spots, streaks or blotches. With C there are also yellow concentric patterns on the older leaves.

A. A symptomless carrier.

T. repens. A. D.

A symptomless carrier with both strains.

Vicia faba. A-D.

Local. D. No reaction.

A. Necrotic lesions develop.

B. There are purple necrotic rings and the remaining tissue becomes yellow.

Systemic. D. Diffuse chlorotic spots develop.

A. There is a chlorotic spotting with a necrotic network.

B. C. No symptoms but the virus can be recovered.

Vigna sesquipedalis. A-D.

Local. D. No reaction.

A. There are chlorotic spots but later the whole leaf becomes chlorotic.

B. There are necrotic lesions and the rest of the leaf becomes chlorotic. They soon absciss.

C. In addition to the symptoms with B there is a marked epinasty.

Systemic. All induce a veinclearing, chlorotic spotting and mottle. B. may cause a stunting of the plants.

V. unguiculata. A-D.

Local. D. No reaction.

A. After a chlorotic spotting the leaves become flaccid.

B. There are necrotic lesions and the remaining leaf tissue becomes yellow. The leaves soon drop.

C. There is a marked epinasty as well.

Systemic. B. C. D. Chlorotic spots develop and later a mottle.

A. In addition there are dark green blisters with the mottle, and later a necrotic sheen. The leaves are malformed and there may be necrotic stem streaks.

Voandzeia subterranea. A-D.

Local. Only with $\mathrm{C}$ are there chlorotic blotches.

Systemic. With all strains there may be a veinclearing, mottle and crinkle. Fig. 5C. Some plants with $\mathrm{A}$ and $\mathrm{D}$ are symptomless carriers.

\section{IDENTIFICATION.}

The characteristic feature of this group of viruses is the well-defined chlorotic ring and line or ringspot reaction on the inoculated leaves of bean. Similar symptoms on some varieties of bean are described by Cheo and Zaumeyer (8) with their strain of tobacco ringspot virus from bean, and with the green strain of tobacco ringspot.

However, none of the four isolates recorded here can be fully identified with either of these strains. There may be similarities in symptom expression on several hosts, 
e.g. on Glycine max the D isolate resembles the bean strain of Cheo and Zaumeyer, and on white lupin the A isolate is similar to the green strain, but on other plants there are considerable differences.

Further, Dolichos lablab which is used as a differential host by Cheo and Zaumeyer when comparing four strains of tobacco ringspot virus, is a symptomless carrier for three of the isolates described here, viz. A. C. D. and is not susceptible to the fourth.

On cowpea, the bean strain induces a systemic necrosis, which does not occur with any of these strains; and on broad bean it causes systemic necrotic rings which are not present with any of these isolates.

The type tobacco ringspot virus on bean usually induces local necrotic spots, rings or veins followed by systemic necrosis and collapse, Pierce (29) and Price (32). The effect of the viruses described here is mainly chlorotic with only necrotic specks on the trifoliates.

Stubbs (43) described the symptoms of the type virus on peas, which is also necrotic, whereas with these strains it is only chlorotic.

In addition, the host ranges differ considerably.

Although there can be little doubt that the viruses recorded here are related to the tobacco ringspot group, there is no complete correlation with any of the strains previously described. They are therefore reported as additional strains and named bean chlorotic ringspot viruses $\mathrm{A}, \mathrm{B}, \mathrm{C}$ and $\mathrm{D}$.

\section{4.-BEAN LOCAL CHLOROSIS VIRUSES}

The characteristic feature of the viruses in this group is the local reaction on the bean, viz. a distinct chlorotic spotting. This reaction occurred with isolates from several plant species. In other details these seven isolates differ from one another. They are therefore not considered to be one virus, but strains of the virus linked by their common local reaction on the bean. (Only strains $F$ and $G$ differ slightly in the systemic reaction on bean.)

Natural source of virus and locality:

Strain A.-Medicago denticulata. Stellenbosch.

B.-Lathyrus odoratus. Pretoria and district.

C.-Phaseolus vulgaris. Rustenburg.

D.-Crotalaria juncea. Salisbury.

E.-Glycine max. Pretoria, Nylstroom, Potchefstroom.

F.-Phaseolus vulgaris. Pretoria district.

G.-Trifolium incarnatum. Stellenbosch.

PHYSICAL PROPERTIES

\begin{tabular}{|c|c|c|c|}
\hline Virus. & $\begin{array}{c}\text { Thermal } \\
\text { inactivation } \\
\text { point }{ }^{\circ} \mathrm{C} \text {. }\end{array}$ & $\begin{array}{l}\text { Longevity in } \\
\text { vitro-days. }\end{array}$ & Dilution end point. \\
\hline 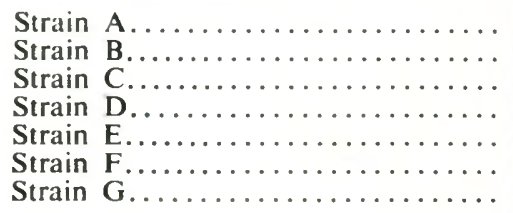 & $\begin{array}{l}60-62 \\
58-60 \\
58-60 \\
62-65 \\
56-58 \\
60-62 \\
56-58\end{array}$ & $\begin{array}{l}2-3 \\
2-3 \\
1-2 \\
1-2 \\
1-2 \\
3-4 \\
1-2\end{array}$ & $\begin{array}{l}1: 2,000-1: 5,000 \\
1: 1,000-1: 2,000 \\
1: 1,000-1: 2,000 \\
1: 2,000-1: 5,000 \\
1: 1,000-1: 2,000 \\
1: 2,000-1: 5,000 \\
1: 2,000-1: 5,000\end{array}$ \\
\hline
\end{tabular}


Transmission: All are transmissible both by mechanical sap inoculation and by Aphis craccivora.

Symptoms on naturally infected plants (i.e. source of virus).

Strain A.- Medicago denticulata. The leaves showed varying degrees of chlorosisspots, streaks, mottle and mosaic. They were small and crinkled and the plants were stunted. The incidence of infection was high.

Strain B.-Lathyrus odoratus. The leaves had chlorotic streaks or veinbands and they were small and puckered.

Strain C.-Phaseolus vulgaris var. Black Wonder. Most leaves were puckered and had small chlorotic specks. The plants were slightly stunted.

Strain D.-Croralaria juncea. Some leaves had chlorotic spots, but most showed a mosaic, with dark green veinbands. They were also slightly malformed and rosetted; and the plants were stunted.

Strain E.-Glycine max. The leaves were mottled and puckered, and the plants were slightly stunted with a proliferation of the lateral shoots.

Strain F.-Phaseolus vulgaris $(a)$ var. Long Tom. The leaves were mottled and severely curled and malformed. There were occasional necrotic stem streaks, and the pods had marked necrotic lesions. (b) var. Haricot. The young leaves had a chlorotic network and were curled. Older ones were crinkled and mottled with dark green blisters.

Strain G.-Trifolium incarnatum. The leaves showed irregular chlorosis and they were small, crinkled and malformed. The plants were severely stunted.

HOST RANGES.

Host Plant.

Arachis hypogaea $\mathrm{L}$

Crotalaria juncea

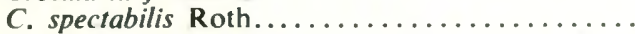

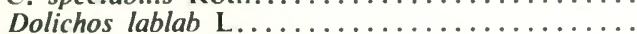

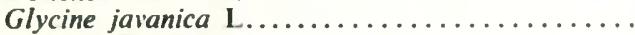

G. $\max$ (L.) Merr.

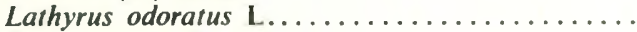

Lupinus albus $\mathrm{L}$

L. Inteus L...........

L. mutabilis Sweet.

Medicago denticulata

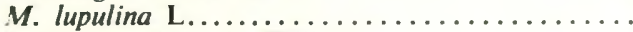

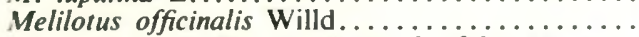

Phaseolus acutifolius Gray var. latifolius Freem.

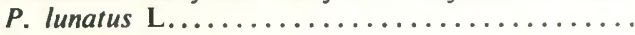

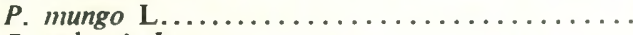

P. vulgaris $\mathrm{L}$..

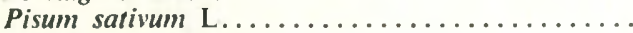

Trifolium fragiferum

T. hybridum $\mathrm{L}$.

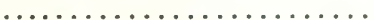

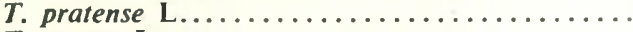

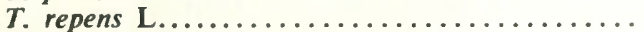

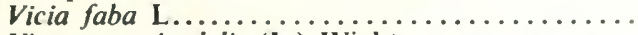

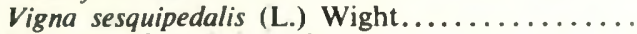

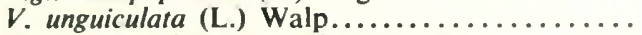

Voandzeia subterranea Thouars.

Strains.

\begin{tabular}{|l|l|l|l|l|l|l|}
\hline A & B & C & D & E & F & G \\
\hline
\end{tabular}




\section{REACTION OF SUSCEPTIBLE SPECIES}

Not all strains were tested on every host plant, but the available results are compared below. The letters, $A-G$ indicate the strains.

Arachis hypogaea. A. E. G.

Local. No reaction.

Systemic. A. The young leaves develop a mottle with a dark green midrib.

E. Chlorotic spots develop on the young leaves in 14 days. Later leaves are chlorotic with dark green islands.

G. There is a chlorotic mottle on most leaves.

Crotalaria juncea. A. C. D. F. G.

Local. A. C. G. No reaction.

D. Chlorotic spots develop in eight days. effect.

F. In seven days large necrotic lesions develop which fuse later to give a " scorch"

Systemic. A. G. After a veinclearing of the young leaves, the next formed are mottled with dark green blisters. They are also crinkled and curled and the plant is stunted.

C. In addition to the above there is a severe malformation and some leaves are almost stringlike. Fig. 6A.

D. F. Similar to C. with necrotic specks. With F, also a vascular necrosis which results in the death of the plant.

Crotalaria spectabilis. A. B. C. D. F. G.

Local. Only with D are there small chlorotic spots.

Systemic. A. D. The young leaves develop a chlorotic network and speckling. The next leaves are crinkled with wavy margins, and are chlorotic with irregular dark green islands.

C. F. After a veinclearing the leaves develop dark green veinbands.

B. The new leaves have conspicuous white streaks which result in a malformation. (See report on sweet pea virus diseases for photograph.)

G. There is a mild speck mottling.

Dolichos lablab.

A symptomless carrier for A. C. D.

Glycine javanica. A. C. D. F. G.

F. G. Symptomless carriers.

Local. A. D. Chlorotic spots develop in 4-5 days.

C. No reaction.

Systemic. A. D. A diffuse mottle develops.

C. A chlorotic spotting is followed by chlorotic streaks. Glycine max. B-G.

Local. B. C. D. No reaction.

G. There is a general chlorosis. specks.

E. F. Chlorotic stars, rings and spots develop. With F. there are also necrotic

Systemic. B. C. Only a diffuse mottle develops.

D. After a chlorotic spotting, there is a mottle of the leaves which are crinkled.

G. There may be chlorotic spots with necrotic rings on the older leaves, while the younger ones are mottled.

E. F. There is first a veinclearing, then chlorotic spotting and a mottle. Later, necrotic specks develop. The leaves are crinkled and the plants are stunted.

Lathyrus odoratus. A. B. C. D. F. G.

Local. No reaction.

Systemic. C. There is only a diffuse mottle.

F. The leaves are elongated and rolled and show chlorotic streaks. 
A. D. G. The early symptoms are similar to $F$, but later formed leaves have a mottle with well-defined dark green veinbands.

B. There is a mosaic mottle on most leaves and the stems show necrotic streaks. (See report on the virus diseases of sweet pea.)

Lupinus albus. A-G.

Local. A. B. C. No reaction.

D. F. There are small necrotic specks.

E. After the necrotic specks have developed, the leaves become chlorotic and soon drop.

Systemic. A. After a chlorotic spotting of the young leaves, there are dark green blisters on later formed leaves which are reduced in size. The plant is stunted.

C. E. There is an initial mosaic but later leaves are quite chlorotic. They are small, have wavy margins and remain folded. Many absciss.

B. D. G. In addition to the symptoms for C. E. there are necrotic specks on the leaves; and necrotic stem streaks with $D$.

Lupinus luteus. A-G.

Local. A. B. C. F. G. No reaction.

D. Chlorotic spots develop.

E. The leaves are chlorotic with necrotic specks and they soon drop.

Systemic. A. B. The leaves are mottled and crinkled and they remain folded.

C. E. G. There is also a malformation of the leaves and the plant is stunted. blisters.

D. F. The malformation is severe and the leaves are stringlike with dark green

With $F$. there are also necrotic stem streaks.

Lupinus mutabilis. A. C. D. G.

Local. No reaction.

Systemic. A. D. The leaves are chlorotic with dark green blisters, and they are malformed. The plant is rosetted.

C. G. The plants collapse after necrosis.

Medicago lupulina. A. C. D. F. G.

Local. Only with $F$ is there a reaction. Necrotic lesions develop, and fuse, and the leaves collapse.

Systemic. The symptoms are similar for all strains, viz. a chlorotic streak mottle and/or dark green veinbands. With $\mathrm{D}$ the leaves are crinkled.

Melilotus officinalis. A. C. D. F. G.

Local. A. C. G. No reaction.

D. F. There are chlorotic spots with dark green rings.

Systemic. C. D. A chlorotic spot mottling develops.

A. In addition the leaves are malformed.

F. G. There are distinct ring and line patterns and the leaves are malformed.

With $F$ there may also be necrotic specks.

Phaseolus acutifolius. A. C. D. E. F. G.

Local. All these strains induce a chlorotic and necrotic reaction-usually chlorotic spots with necrotic veins. $\mathrm{C}$ and $\mathrm{E}$ also induce necrotic spots and $\mathrm{G}$ also causes necrotic rings round the chlorotic spots.

Systemic. A. C. F. After a veinclearing there is a mottle with slight malformation.

D. E. G. In addition there is a necrosis of the veins; or necrotic specks with $G$.

P. lunatus. A. C. D. E. F. G.

Local. Except for D, these strains induce chlorotic spots or large blotches. D shows no reaction.

Systemic. D. After a veinal necrosis the leaves drop.

The other strains cause a chlorotic vein flecking.

P. mungo. A. C. D. E. F. G.

Local. A. D. There are chlorotic spots. 
F. There are necrotic spots.

E. G. There are both chlorotic spots and necrotic specks or veins.

Systemic. A. E. After a veinclearing there are chlorotic spots or irregular areas. sheen.

D. F. G. In addition, necrosis sets in. in the chlorosis and the leaves have a necrotic

C is latent in this plant.

P. vulgaris var. Canadian Wonder. A-G.

Local. All strains cause distinct, vivid chlorotic spots. Fig. 6C. These may fuse with closely adjacent ones, Fig. 6D, but usually they retain their individuality.

Systemic. A-E. After a clearing of the veins there is a chlorotic spotting and then a mottle.

With $\mathrm{D}$ and $\mathrm{E}$ there are also dark green veinbands.

F. G. In addition the young leaves develop necrotic specks and they are malformed. The pods have sunken dark green areas and they are misshapen.

vars. Black Wonder, Idaho Refugee, Long Tom, S.A. Black and White,

Tendergreen and Victor show symptoms similar to those on Canadian Wonder. var. Haricot may develop local chlorotic specks with strains A. D. E. F., but,

on the trifoliate leaves the reaction is the same as that on Canadian Wonder. Pisum sativum. A-G.

Local. B. C. E. G. No reaction.

A. F. After a veinal necrosis the leaves collapse.

D. There may be chlorotic specks.

Systemic. A. B. F. After a veinclearing and chlorotic spotting there is a mottle on later formed leaves. Necrosis sets in. in the chlorosis, or there are necrotic stem streaks and the plant collapses.

C. G. There is a veinclearing, chlorotic spotting and mottle, and the plants are rosetted.

D. E. In addition to the mottle, the leaves are malformed and small, and the tendrils are abnormally curled. The older leaves have an almost white vein etching. Trifolium fragiferum. F.

Local. Necrotic spots develop after six days.

Systemic. A diffuse chlorotic (almost white) spotting occurs.

T. hvbridum. A-G.

Local. A. C. D. E. G. No reaction.

B. F. There is a chlorotic spotting.

Systemic. A. B. C. G. Chlorotic streaks following the veins develop.

D. F. There is a chlorotic spotting on the young leaves, and on later formed ones there is a vivid yellow streak mosaic. With D the plants are also stunted.

E. A symptomless carrier.

T. incarnatum. A-G.

Local. B. C. E. F. No reaction.

A. D. Chlorotic spots develop in 5-6 days.

G. There are chlorotic spots with necrotic rings and necrotic centres.

Systemic. B. C. E. After a veinclearing there is a mosaic mottle, and slight puckering of the leaves.

D. G. There is a chlorotic network, followed by a chlorotic spotting and later a mosaic. The leaves are crinkled and malformed, and the plant is rosetted and stunted.

$F$. In addition to the symptoms for $D$ and $G$, necrosis sets in, in the chlorotic spots.

A. After 10 days the young leaves show a veinclearing. Later formed leaves have a mosaic with dark green veinbands and blisters. They are severely crinkled, with wavy margins. The plant is extremely stunted and rosetted, and may collapse. T. pratense. A. D. F. G.

Local. A. D. F. G. No reaction. 
Systemic. A. In 10 days the veins are chlorotic, and later a mosaic develops. The leaves are crinkled and may be malformed with necrotic areas.

D. F. There is a chlorotic streak mottle, but $\mathrm{D}$ may be latent in this host.

G. After a veinclearing there are short dark green veinbands and a dark green midrib. The leaves are crinkled or slightly malformed.

T. repens. F. G.

A symptomless carrier for both strains.

Vicia faba. A-G.

Local. B. C. No reaction.

A. There are chlorotic spots with small necrotic specks in four days.

D. Small necrotic lesions develop.

F. In 4-5 days there are large necrotic lesions which spread and fuse with adjacent ones. As the leaves mature, the background becomes yellow. Fig. 6B.

Systemic. A. B. C. D. There is a chlorotic network and spotting, with a mottle on later formed leaves.

F. Occasionally the local necrosis will spread down the petiole and thence into the stem. This results in the collapse of the plant.

E. G. Symptomless carrier.

Vigna sesquipedalis. A. D. E. F. G.

Local. A. E. F. G. Chlorotic spots develop in 5-6 days.

D. There are first chlorotic ringspots, but later the whole leaf becomes chlorotic.

Systemic. A. No reaction.

D. E. F. G. There are chlorotic spots and later a mottle.

V. unguiculata. A-G.

Local. D. No reaction.

A. B. C. E. G. There are necrotic lesions in 4-5 days.

F. Although there is no necrosis, the leaves become flaccid and absciss.

Systemic. B. No reaction.

A. C. E. F. G. After a veinclearing there are chlorotic specks, and, on later formed leaves, a mottle.

D. The mottle is accompanied by dark green blisters.

Voandzeia subterranea. A. C. D. F. G.

Local. A. C. F. G. No reaction.

D. There are chlorotic spots with necrotic rings in seven days.

Systemic. All induce a chlorotic spotting followed by a mottle. In addition. D causes dark green veinbands.

\section{IDENTIFICATION.}

The feature which links these seven strains is the vivid chlorotic spotting on the inoculated leaves of the bean.

A similar symptom has been described by Ainsworth with the "sweet pea streak" virus (1), Zaumeyer with alfalfa yellow mosaic virus (53) and Smith and Markham with a virus from Ligusticum (40). Van der Want (50) reports that on the variety Servus. local chlorotic spots are sometimes produced with two strains of bean yellow mosaic virus.

However, although there may be other similarities between these four viruses and some of the strains described here, there is no complete correlation, e.g. strain G resembles alfalfa yellow mosaic in its reaction on bean, pea and broad bean, but on other hosts it differs considerably. Further, the alfalfa yellow mosaic can infect solanaceous plants, whereas the host range of this virus is restricted to the Leguminosae.

During a survey of legume virus diseases in England (22) three strains causing this characteristic local reaction on bean were isolated from naturally infected species of Phaseolus, Pisum, Vicia, Trifolium, Medicago, Melilotus and Lathyrus. These strains 
were designated A. B. and C, and they have also been found in this country on Phaseolus, Lathyrus and Medicago spp. A further four strains have been isolated from other naturally infected host plants, viz. Crotalaria. Glycine, Phaseolus and Trifolium spp. and are named bean local chlorosis virus, strains D. E. F. and G.

\section{BEAN NECROSIS VIRUS}

A virus found on naturally infected Crotalaria spectabilis caused extremely severe local and systemic necrosis on bean. A similar reaction on bean developed with isolates from Dolichos lablab and Glycine javanica, but on some other host plants these isolates differed.

In this account the virus is described as a whole, and the variations are given under the appropriate species.

Physical properties: Thermal inactivation point $65-70^{\circ} \mathrm{C}$.

Longevity in vitro 6-7 days.

Dilution end point 1:5,000-1:10,000.

Transmission: Mechanical sap inoculation.

Not by Aphis craccivora.

Host range: Arachis hypogaea L., Crotalaria juncea L., C. spectabilis Roth., Dolichos lablab L., Glycine javanica L., G. max (L.) Merr., Lathyrus odoratus L., Lupinus albus L., L. luteus L., L. mutabilis Sweet., Medicago lupulina L., Melilotus officinalis Willd., Phaseolus acutifolius Gray var. latifolius Freem., P. lunatus L., P. mungo L., $P$. vulgaris L., Pisum sativum L., Trifolium hybridum L., $T$. incarnatum L., $T$. pratense L., Vicia faba L.. Vigna sesquipedalis (L.) Wight., V. unguiculata (L.) Walp., Voandzeia subterranea Thouars.

\section{REACTION OF SUSCEPTIBLE SPECIES}

Arachis hypogaea.

Local. No reaction.

Systemic. The leaves have chlorotic areas with dark green islands. Crotalaria juncea.

Local. There are necrotic lesions and the leaves drop.

Systemic. After 12 to 14 days there is a vein clearing of the young leaves, followed by a chlorotic spotting and a mottle mosaic. The leaves are rolled and the plant is stunted.

C. spectabilis.

Local. No reaction.

Systemic. After a veinclearing and spotting of the young leaves, later ones are very chlorotic and rolled and crinkled. The plant is stunted.

Dolichos lablab.

Local. No reaction.

Systemic. The young leaves develop a chlorotic network. The next formed leaves are mottled and slightly crinkled.

Glycine javanica.

Local. There are small necrotic specks and the leaf becomes chlorotic.

Systemic. Chlorotic spots and vein flecks develop on most leaves. On some there are large irregular chlorotic blotches, and the leaves are puckered.

Glycine max.

Local. Small necrotic specks appear in 10 days.

Systemic. The young leaves develop chlorotic veins, spots and flecks. Necrosis develops in the chlorosis of the old leaves, resulting in a malformation. The plant is stunted. 


\section{Lathyrus odoratus.}

Local. No reaction. wards.

Systemic. Most leaves show a dark green streak mottle and they are rolled downLupinus albus.

Local. There are chlorotic spots.

Systemic. In 11 to 12 days the young leaves develop a veinclearing with chlorotic spots. Later leaves are small and malformed with dark green blisters. They remain folded and the margins are irregular. The growing point is rosetted and the plant is stunted. Many older leaves drop.

L. luteus.

Local. Small chlorotic spots may develop.

Systemic. A veinclearing and chlorotic spotting of the young leaves develops in eight to nine days. New leaves remain folded with the tips twisted. They are mottled and small. The plant is stunted.

L. mutabilis.

Local. No reaction.

Systemic. The young leaves curl up, and they are spotted. Later ones are very small and chlorotic. Many drop.

Medicago lupulina.

A symptomless carrier.

Melilotus officinalis.

Local. No reaction.

Systemic. Occasional irregular vivid chlorotic areas and some dark green ringspots develop. Fig. 7B. The virus is recoverable from symptomless leaves.

Phaseolus acutifolius.

Local. There may be necrotic specks.

Systemic. The young leaves curl back and have veins which are chlorotic then necrotic. The plant collapses.

$P$. lunatus.

Local. Small necrotic lesions appear in four days. These have chlorotic haloes.

Systemic. There are chlorotic vein flecks on most leaves in three weeks. Fig. 7C. P. mungo.

Local. In five days there are necrotic rings.

Systemic. There is a chlorotic spotting and then a mosaic with a slight distortion. $P$. mungo with the B isolate.

A symptomless carrier.

$P$. vulgaris var. Canadian Wonder.

Local. There is a severe necrosis of the veins and petioles. Fig. 7E.

Systemic. In 12 days the young leaves start to curl round and back. and have a veinclearing. Necrosis sets in, in the veins causing a malformation. These leaves drop and very few more are formed. Fig. 7A. The old leaves have large chlorotic blotches.

var. Haricot.

Local. In seven to eight days the leaves have necrotic veins.

Systemic. This necrosis spreads along the petioles and up the stem. The young leaves show a necrotic sheen and the growing point collapses in 14 to 15 days.

Pisum sativum.

Local. The leaves collapse after a general necrosis.

Systemic. In eight to nine days a veinclearing of the young leaves develops. Later leaves have a mottle or mosaic with necrosis. The growing point is rosetted and the plant is stunted and may collapse.

$P$. sativum. With the $\mathrm{B}$ isolate.

Local. No reaction. 
Systemic. Only a chlorotic network of the young leaves develops in 13 days. Trifolium hybridum.

Local. No reaction.

Systemic. After a chlorotic spotting on the young leaves, the next show alternate streaks. Necrosis sets in, in the chlorosis. Fig. 7D.

The $\mathrm{B}$ isolate is latent.

T. incarnatum.

Local. There are necrotic veins on chlorotic leaves.

Systemic. In a week the young leaves show a chlorotic network, and vein flecks. Later leaves have a mosaic with dark green veinbands and they are crinkled. The plant is very stunted and usually collapses.

The $\mathrm{B}$ isolate is latent.

T. pratense.

Local. No reaction.

Systemic. There are diffuse dark green veinbands. Vicia faba.

Local. There are necrotic rings on chlorotic leaves.

Systemic. After 10 days the young leaves show a chlorotic network with small chlorotic spots. Later leaves are mottled.

V'igna sesquipedalis.

Local. No reaction.

Systemic. The young leaves develop chlorotic spots and flecks, and later veinbands. $V$. unguiculata.

Local. In five days the leaves show necrotic spots and they drop.

Systemic. Only a diffuse mosaic develops on the young leaves of some varieties. The virus is recoverable from symptomless plants.

Voandzeia subterranea.

A symptomless carrier.

Natural source of virus:

(a) Crotalaria spectabilis. Potchefstroom, Pretoria and district. There was a chlorotic mottle with dark green veinbands and blisters. On older leaves there was necrosis in the chlorosis, and there were also necrotic stem streaks. The plants were stunted and rosetted.

(b) Dolichos lablab. Prinshof Experimental Station, Pretoria. The younger leaves had chlorotic spots; and the older ones, a mottle with dark green veinbands and blisters.

(c) Glycine javanica. An experimental plot adjacent to (b). There were irregular chlorotic areas on most leaves, which were also puckered.

\section{IDENTIFICATION}

The dominant feature of this virus is the severe local and systemic necrosis on bean. This type of symptom occurs with many other viruses, with which this one will be compared:-

(a) The reaction appears to be very similar to photographs of black root, Jenkins $(19,20)$ which is the symptom expression of common bean mosaic virus on particular variety lines of bean. However, as Canadian Wonder has been used throughout these experiments, and has shown the more typical reaction of bean mosaic (veinbanding, rolling etc.) that virus is not the causal agent. This is further confirmed by the great differences in host range and physical properties. 
(b) There are several strains of alfalfa mosaic virus which may result in similar symptoms on some varieties of bean, e.g. the tuber necrosis and potato calico strains of Oswald (26), alfalfa mosaic $\mathrm{N}$ of McWhorter (23) and alfalfa yellow mosaic virus of Zaumeyer (53). However, on other hosts the symptoms differ considerably from those caused by this virus, and, with the first three-named strains, the property values differ also.

(c) Of the several bean yellow mosaic virus strains, only the X-strain of McWhorter (24) and the severe yellow strain of Thomas and Zaumeyer (49) induce both local and systemic necrosis on some varieties of bean. Nevertheless, the differences in symptom expression on other host plants, host ranges and physical properties are too great for this virus to be identified with either strain.

(d) On bean, pea and soybean this virus induced symptoms similar to those caused by the pea streak virus, Chamberlain (7), but on other plants they are dissimilar. Further, the pea streak virus withstands higher temperatures and dilutions and longer ageing than this one.

(e) This virus cannot be identified with the bean Southern mosaic, Zaumeyer and Harter (55) as the latter has a very restricted host range and high physical property values.

( $f$ ) There are too few details of the bean yellow necrosis virus Johnson (21) and the Dolichos mosaic virus Capoor and Varma (5) for an accurate comparison to be made.

$(g)$ There are other non-legume viruses which result in a similar type of reaction on certain varieties of bean, e.g. tobacco necrosis virus causing stipple streak of bean, van der Want (50) and a tobacco streak strain causing red node of bean, Thomas and Zaumeyer $(47,48)$. Also the tobacco ringspot virus Pierce (30), tobacco broken ringspot virus, Smith and Markham (39) and a cucumber mosaic virus strain isolated from spinach by Fulton (12). With none of these is there a complete correlation.

From this account of the data available, it seems that the virosis described above cannot be wholly identified with any previously recorded disease.

It shows some similarities with several viruses and is probably related to one of them-meanwhile it is named the bean necrosis virus.

\section{6.-BEAN VIRUS COMPLEX}

When beans were inoculated with the sap from several naturally infected Phaseolus vulgaris and Crotalaria spectabilis plants, two distinct types of local lesions developed, viz. chlorotic spots or blotches and necrotic specks. After several transfers to and from other hosts, it became evident that more than one virus was involved.

For the convenience of others who may have to identify bean viruses, the complex is firstly described as such, and then the symptoms of the individual components are compared.

The virus causing the local chlorosis appears to be identical with the bean local chlorosis virus $\mathbf{A}$, which has already been described and which occurs naturally on its own.

The second component, which results in the local necrotic lesions on bean, is named bean necrotic speckle virus. Apparently, it is not found alone in the field, but only in the complex. 
Natural source of virus complex and locality:

(a) Phaseolus vulgaris. Pretoria and district, Groblersdal and Bronkhorstspruit.

Several varieties showed large chlorotic blotches on the older leaves, and a mottle on the younger ones. These were also crinkled and slightly malformed. Most plants were stunted. On some varieties e.g. Rooikrans there were necrotic specks on the leaves and sunken necrotic areas on the pods.

(b) Crotalaria spectabilis. Potchefstroom.

The leaves had dark green veinbands with irregular chlorotic areas interveinally. There were short necrotic stem streaks and the plants were stunted.

Throughout this description, the following abbreviations will be used:-

Comp.-virus complex.

BLCV. A.-bean local chlorosis virus A.

BNSV.- - bean necrotic speckle virus.

Physical properties: Thermal inactivation point $60-64^{\circ} \mathrm{C}$.

Longevity in vitro $2-3$ days.

Dilution end point $1: 1,000-1: 5,000$.

These values refer to the complex and to the two components.

Transmission: Mechanical sap inoculation.

Aphid transmission tests were inconclusive.

Host range: Arachis hypogaea L., Crotalaria juncea L., C. spectabilis Roth., Glycine max (L.) Merr., Lathyrus odoratus L., Lupinus albus L., L. luteus L., L. mutabilis Sweet.. Medicago lupulina L., M. sativa L., Melilotus officinalis Willd., Phaseolus acutifolius Gray var. latifolius Freem., P. lunatus L., P. mungo L., P. vulgaris L., Pisum sativum L., Trifolium hybridum L., $T$. incarnatum L., $T$. pratense L., $T$. repens $L$., Vicia faba L., Vigna sesquipedalis (L.) Wight., V. unguiculata (L.) Walp., Voandzeia subterranea Thouars.

BLCV. A is not able to infect Glycine max, Medicago sativa or Trifolium repens.

\section{REACTION OF SUSCEPTIBLE SPECIES}

Arachis hypogaea.

Local. No reaction.

Systemic. With all three viruses a mottle develops.

Crotalaria juncea.

Local. Comp. and BNSV. In nine days there are chlorotic spots with necrotic centres.

BLCV. A. No reaction.

Systemic. Comp. The growing point curves strongly to one side. The leaves are puckered with wavy margins and they have dark green blisters. The plant is rosetted and stunted.

BLCV. A. There is a crinkling of the leaves with a mottle and dark green blisters.

BNSV. After a veinclearing of the young leaves, later formed ones are mottled with a necrotic sheen. The plant is stunted.

C. spectabilis.

Local. No reaction.

Systemic. The symptoms with all three viruses include a veinclearing and/or chlorotic spotting, followed by a mottle with dark green blisters. The leaves are crinkled and the plant is slightly stunted.

Glycine max.

Local. Comp. and BNSV. Chlorotic spots develop in nine days.

Systemic. Both viruses cause a chlorotic spotting on the young leaves, and a mottle and malformation on later formed ones. Fig. 8D.

With BNSV. there are also necrotic specks on the old leaves. 
Lathyrus odoratus.

Local. Comp. and BNSV. Small necrotic lesions develop.

BLCV. A. No reaction.

Systemic. With all three, the leaves are rolled and mottled. There are also dark green veinbands with BLCV. A.

Lupinus albus.

Local. Comp. and BNSV. There are small necrotic lesions and the leafiets absciss.

BLCV. A. No reaction.

Systemic. The three viruses induce a veinclearing or chlorotic spotting on the young leaves which remain folded. Later formed leaves are small and chlorotic with dark green blisters, and the plant is rosetted.

With the complex, the stem may become necrotic and the plant collapses.

L. luteus.

Local. No reaction.

Systemic. Comp. The young leaves are mottled and remain folded. Later formed leaves are malformed and almost stringlike, with large dark green blisters. The plant is stunted and rosetted.

BNSV. Chlorotic spots may develop. Later leaves have a dark green band along the midrib which is puckered, and the margins are rolled upwards. The plant is rosetted.

BLCV. A. The leaves are mottled, folded and crinkled.

L. mutabilis.

Local. Comp. There is a general necrosis and the leaflets absciss.

BNSV. and BLCV. A. No reaction.

Systemic. Comp. Necrotic stem streaks develop, the growing point curls to one side, and the plant eventually collapses.

BNSV. If the plants are young when infected, the reaction is similar to that of the complex. On older plants, there is a mottle on the leaves which are small and stringlike, and rosetted. blisters.

BLCV. A. The leaves are severely curled and very chlorotic with dark green

Medicago lupulina.

Local. No reaction.

Systemic. With the complex there are areas with mosaic markings, but with the other two viruses there is a mottle with dark green veinbands.

M. sativa.

Local. No reaction.

Systemic. Both the complex and BNSV cause a diffuse chlorotic spot mottle, and a slight malformation of the leaves.

Melilotus officinalis.

Local. No reaction.

Systemic. Comp. and BLCV. A. There is a mottle with chlorotic streaks and the leaves are malformed.

BNSV. Only a chlorotic mottle develops.

Phaseolus acutifolius.

Local. All three viruses induce a chlorotic spotting with necrotic veins or rings. The leaves collapse.

Systemic. Comp. The young leaves develop a veinclearing with necrosis, and they are severely curled. Later leaves have a speck mottle.

BNSV. This necrosis usually results in the collapse of the growing point. Should any secondary shoots develop, they have small, malformed and mottled leaves.

BLCV. A. There is a yellow network only. 


\section{P. lunatus.}

Local. Comp. Chlorotic spots with necrotic specks develop.

BNSV. There are small necrotic specks in nine days.

BLCV. A. Chlorotic spots develop in four days.

Systemic. Comp. and BLCV. A. After a veinclearing, there are chlorotic flecks along the veins on most leaves.

BNSV. On the first trifoliates to show symptoms, there is a chlorotic network which soon becomes necrotic. Later formed leaves are speckled.

P. mungo.

Local. Same as for P. lunatus. ring.

Systemic. Comp. The younger leaves develop chlorotic spots, each with a necrotic

BNSV. After a chlorotic spotting on the young leaves, the next formed have dark green veinbands with irregular shaped chlorotic areas, which cause a distortion of the laminae. There are necrotic specks on the older leaves.

BLCV. A. Irregular chlorotic areas develop on some leaves.

$P$. vulgaris var. Canadian Wonder.

Local. Comp. In 4-5 days small necrotic specks develop which may fuse with closely adjacent ones. After six days there are also chlorotic spots, which develop independently from the specks. Fig. 8A.

BNSV. In 2-3 days necrotic specks develop.

BLCV. A. There are chlorotic spots in 4-5 days.

Systemic. Comp. The first trifoliates show large chlorotic blotches in 12-14 days. Young leaves have chlorotic spots, and later ones develop a mottle with dark green blisters. They are slightly puckered and may have twisted tips. The pods are mottled. Fig. 8B.

BNSV. After a chlorotic spotting of the young leaves, later ones develop a mottle, with dark green blisters. These leaves are malformed and elongated, and the plant is stunted.

BLCV. A. There is a veinclearing of the young leaves; later formed ones are mottled, crinkled and slightly malformed.

vars. Black Wonder and S.A. Black and White.

Local. Comp. and BLCV. A. Same as for Canadian Wonder.

BNSV. There are necrotic rings in addition to the necrotic specks.

Systemic. Same as for Canadian Wonder.

vars. Idaho Refugee, Long Tom. Tendergreen and Victor.

Local. Comp. Very few necrotic specks develop.

BNSV. and BLCV. A. Similar to that on Canadian Wonder.

Systemic. Same as for Canadian Wonder.

var. Haricot.

Local. Comp. In addition to the symptoms described for Canadian Wonder, there is a necrosis of the veins and petioles.

BNSV. There are necrotic specks, veins and petioles, Fig. 8C.

BLCV. A. Same as Canadian Wonder.

Systemic. Comp. and BNSV. There are necrotic specks and stem streaks which may result in the collapse of the plant.

BLCV. A. Similar to Canadian Wonder.

Pisum sativum.

Local. Comp. After a general necrosis the leaves collapse.

BLCV. A. The veins become necrotic and the leaves collapse.

BNSV. Necrotic spots develop.

Systemic. Comp. and BLCV. A. There is a veinclearing of the young leaves. 
Later formed ones are mottled with necrosis setting in, in the chlorosis. The plant usually collapses.

BNSV. Most leaves develop chlorotic spots and veins, which soon become necrotic. The leaves remain folded, the tendrils are abnormally curled and the plant is rosetted. Later, necrotic stem streaks develop, which may lead to the ultimate collapse of the plant.

Trifolium hybridum.

Local. BNSV. There are diffuse chlorotic spots, with dark green rings.

Comp. and BLCV. A. No reaction.

Systemic. BNSV. There are chlorotic spots, streaks and ringspots.

Comp. and BLCV. A. A chlorotic streaking develops.

$T$. incarnatum.

Local. Comp. Chlorotic spots with necrotic rings develop.

BNSV. There are necrotic rings and a general chlorosis.

BLCV. A. Chlorotic spots develop.

Systemic. All three viruses cause a veinclearing, and later a mottle with dark green areas, veinbands or blisters. With the complex and BLCV. A. the leaves are severely crinkled. With BNSV. necrosis may set in, in the chlorosis and the plant may collapse.

$T$. pratense.

Local. Comp. and BNSV. Small necrotic lesions may develop.

BLCV. A. No reaction.

Systemic. Comp. There are chlorotic blotches on the old leaves and chlorotic streaks on the younger ones. Necrosis may set in, in the latter, resulting in a distortion of the laminae.

BLCV. A. Similar symptoms develop.

BNSV. This virus is latent in the young leaves.

T. repens.

Local. No reaction.

Systemic. Comp. and BNSV. A chlorotic streak mottle develops, or there are no symptoms.

Vicia faba.

Local. Comp. Small necrotic specks develop.

BNSV. In addition there are necrotic rings.

BLCV. A. There are necrotic specks and chlorotic spots in 4-5 days.

Systemic. Comp. The older leaves develop large necrotic lesions which spread and fuse, and the leaves drop. This necrosis may continue into the growing point which then collapses: or the young leaves may be mottled.

BNSV. Very diffuse chlorotic spots with necrotic specks develop on the young leaves. Later formed leaves have almost yellow spots which soon become necrotic. Most leaves drop.

BLCV. A. After a chlorotic spotting, there is a mottle. Vigna sesquipedalis.

Local. Comp. There are chlorotic spots with necrotic specks and veins. The leaves soon drop. Fig. 8E.

BNSV. Only the necrosis develops.

BLCV. A. Only the chlorotic spotting occurs.

Systemic. Comp. and BNSV. There is a veinclearing of the young leaves. Later formed ones have dark green specks, veinbands and blisters, and they are rolled downward.

BLCV. A. No reaction.

V. unguiculata.

Local. With all three viruses there are necrotic specks and/or veins. 
Systemic. The three viruses induce a chlorotic network followed by a mottle on later formed leaves.

With BNSV. there are also dark green blisters.

Voandzeia subterranea.

Local. Comp. and BNSV. Small chlorotic spots develop.

BLCV. A. No reaction.

Systemic. Comp. There are chlorotic spots and flecks on the young leaves. Later leaves have dark green veinbands and a necrotic sheen.

BNSV. The young leaves have chlorotic spots, with necrosis setting in.

BLCV. A. There is a chlorotic mottle.

\section{IDENTIFICATION.}

This virus complex consists of two distinct components, which differ considerably In their individual symptom expression on most of the host plants tested.

The component causing the local chlorosis on bean has already been designated bean local chlorosis virus $\mathrm{A}$ - one of a group of viroses which result in this characteristic reaction.

On some varieties of bean this same type of local chlorosis occurs with the alfalfa yellow mosaic virus of Zaumeyer (53), but on many other host plants the symptoms do not agree.

With the alfalfa yellow mosaic, bean varieties develop either a local necrosis or a local chlorosis-never both symptoms simultaneously.

The second component, which causes small local necrotic lesions on bean, is named bean necrotic speckle virus. This symptom occurs both locally and systemically on many host plants, and on some species it is lethal.

Again, there are similarities in symptom expression on some varieties of bean, with those caused by alfalfa yellow mosaic virus, but differences on other hosts preclude complete correlation. Further, the host range of alfalfa yellow mosaic includes more susceptible species and it can withstand higher temperatures.

There are several other viruses, which, on some varieties of bean, cause the same combination of symptoms as occur with bean necrotic speckle virus, viz. local necrosis with systemic chlorosis.

The bean mosaic virus 4, Zaumeyer (56) and pod mottle virus, Zaumeyer (58) both have very restricted host ranges, and strong resistance to heating and ageing. The pea streak virus, Chamberlain (7) also withstands a very high dilution.

Although the red node virus, Thomas and Zaumeyer (47), yellow dot virus, Thomas and Zaumeyer (44) and white clover mosaic virus complex, Zaumeyer and Wade (60) do cause both local necrosis and systemic chlorosis, the descriptions of the type of symptom do not agree with those induced by bean necrotic speckle virus.

The local lesion strain of bean yellow mosaic virus, Thomas and Zaumeyer (49) results in similar symptoms on some bean varieties, but there are considerable differences in the symptoms on other plants, the host ranges and physical properties.

In England, a virus similar to the bean necrotic speckle virus was found on broad bean, also in combination with one causing local chlorotic spots on bean (22).

At the time, it was considered a new virus, but from recent literature, it now appears to be related to the lucerne (alfalfa) mosaic virus group.

There is a considerable resemblance between this virus and some of the many strains of lucerne mosaic, in respect of symptoms on several hosts, legume host range, and some physical property values; but it cannot be completely identified with any one of these variants.

It is therefore described here as a possible new strain and named bean necrotic speckle virus. 


\section{BEAN YELLOW MOSAIC VIRUS}

This virus is common on naturally infected Lupinus albus and $L$. angustifolius, in the Western Province. It has therefore been described in the paper on lupin virus diseases.

\section{BEAN YELLOW MOSAIC VIRUS, NECROTIC STRAIN}

This strain was found on naturally infected Lathyrus odoratus in Pretoria and district. It is described under sweet pea virus diseases.

\section{LUPIN VIRUS B}

This virus was also found on beans growing near various species of Lupinus in the Western Province. Details are given in the paper on lupin virus diseases.

In the field the symptoms are mild-only a chlorotic mottle and slight crinkling of the leaves.

\section{PEA WILT VIRUS STRAIN}

In an experimental plot of Kentucky Wonder beans in the Rustenburg area. many plants showed vivid yellow spots on the leaves. There was also mottling, veinbanding and puckering, and the plants were stunted. This virus is described under pea virus diseases.

\section{SUMMARY}

Details are given of bean virus diseases in South Africa, viz. four viruses and their several variants, and one virus complex. Mention is also made of a further two viruses and two strains, which have been described under other headings.

(a) Bean mosaic virus - the presence of this virus was confirmed.

(b) Bean mosaic virus strain-about 12 per cent seed transmission in the variety Canadian Wonder of unknown origin. Differs from the type virus in having a wider host range: and thermal inactivation point of $60-62^{\circ} \mathrm{C}$., and longevity in vitro of $2-3$ days.

(c) Bean chlorotic ringspot virus with four strains - probably related to the tobacco ringspot group. As the name suggests, this virus causes distinct ringspot patterns on the inoculated leaves of bean. It was isolated from Crotalaria juncea, Erythrina caffia, Glycine max and Voandzeia subterranea. The strains withstand heating to between $56-62^{\circ} \mathrm{C}$., ageing between one and four days and dilutions of between $1: 1000-1: 10.000$.

(d) Bean local chlorosis virus and seven variants-isolated from species of Crotalaria, Glycine, Lathyrus, Medicago, Phaseolus and Trifolium. The virus is named after the marked local chlorotic spotting on bean. The thermal inactivation points of the strains vary between $56-65^{\circ} \mathrm{C}$., the longevity in vitro is between one and four days and the dilution end points are between 1:1000 and 1:5000.

(e) Bean necrosis virus-isolated from Crotalaria spectabilis, Dolichos lablab and Glycine javanica. Although the symptoms on the original host plants are mild. on bean there is a lethal necrosis. The virus is inactivated at temperatures of $65-70^{\circ} \mathrm{C}$., after 6-7 days ageing, and at dilutions of between 1:5000-1:10,000. The relationship of this virus to others is uncertain.

( $f$ ) Bean virus complex. With isolates from Phaseolus vulgaris, Crotalaria spectabilis and Glycine javanica, two distinct local reactions developed on bean. One component was identified as a variant of the bean local chlorosis virus, and the other was named bean necrotic speckle virus. The latter is probably related to the lucerne mosaic virus group. For both components the thermal inactivation point is between $60-64^{\circ} \mathrm{C}$., the longevity in vitro 2-3 days, and the dilution end point between 1:1000 and 1:5000. 


\section{Literature Cited}

1. Aissworth, G. C. (1940)...... The identification of certain viruses found infecting leguminous plants in Great Britain. Ann. Appl. Biol., 27: 218-226.

2. BAWDEN, F. C. AND V. D. WANT, Bean stipple-streak caused by a tobacco necrosis virus. J. P. H. (1949) Tijdschr. over Plantenziekten, 55: 142-150.

3. Bridgmon, G. H. and Walker, The relation of southern bean mosaic to black root. PhytoJ. C. (1951) pathology, 41: 865-871.

4. Burkholder, W, H. AND MUlLeR, Hereditary abnormalities resembling certain infectious diseases A. S. (1926) in beans. Phytopathology, 16: 731-737.

5. Capoor, S. P. and Varma, P. M. Enation mosaic of Dolichos lablab Linn., a new virus disease. (1948) Current Sci. (India), 19: 57-58.

6. CAPOOR, S. P. ANd VARma, P. M. Yellow mosaic of Phaseolus lunatus, L. Current Sci. (India), (1948)

7. Chamberlain, E. E. (1939)..... Pea streak (Pisum virus 3). New Zeal. Jour. Sci. and Technol., 20: 365A-381A.

8. Cheo, P. C. And Zaumeyer, W. J. A new strain of tobacco ringspot virus isolated from bean. (1952) PI. Dis. Rptr., 36: 459-465.

9. Doidge, E. M., Bottomley, A. M., A revised list of plant diseases occurring in South Africa. van der Plank, J. E. and Pauer, Science Bulletin No. 346. (Botany and Plant Pathology G. D. (1953)

10. Fajardo, T. G. (1930).......... Series No. 16).

Studies on the mosaic of the bean (Phaseolus vulgaris L.). Phytopathology, 20: 469-494.

11. Fajardo, T. G. (1930)......... Studies on the properties of the bean-mosaic virus. Phytopathology, 20: 883-888.

12. Fulton, J. P. (1950).......... Studies on strains of cucumber virus 1 from spinach. Phytopathology, 40: 729-736.

13. Grogan, R. G. aNd Walker, J. C. A pod-distorting strain of the yellow mosaic virus of bean. (1948) Jour. Agr. Res., 77: 301-314.

14. Grogan, R. G. ANd Walker, J. C. The relation of common mosaic to blackroot of bean. Jour. (1948)

15. HAGEDORN, D. J. (1950) Agr. Res., 77: 315-331.

A cucumber virus strain with a wide leguminous host range. (Abstract) Phytopathology, 40: 11 .

16. Harrison, A. L., Horsfall, J. G. AND BURKHOLDER, W. H. (1932)

17. Horsfall, J. G., Burkholder, W. H. AND REINKING, O. A. (1937)

18. Horsfall, J. G. (1930)........

19. Jenkins, W. A. (1940).........

20. Jenkins, W. A. (1941).........

21. Johnson, E. M. (1946)..........

22. Klesser, P. J. (1951).........

23. MCWHORTER, F. P. (1949).......

24. MCWhorter, F. P. AND Boyle, L. (1946)

25. Milbrath, J. A. (1952).........

26. Oswald, J. W. (1950).........

27. Parker, M. C. (1933)...........

28. Parker, M. C. (1935)...........

Diseases of canning beans in New York. Plant Dis. Rptr., 16: $164-166$.

Diseases of Green Refugee beans in New York in 1937. Plant Dis. Rptr., 21: 318-319.

Diseases of canning crops. Plant Dis. Rptr. Sup., 76: 83-89.

A new virus disease of snap beans. Jour. Agr. Res., 60: 279-288.

A histological study of snap bean tissues affected with blackroot. Jour. Agr. Res., 62: 683-690.

Two legume viruses transmissible to tobacco. Phytopathology, 36: 142-147.

A study of the viruses affecting leguminous plants and the diseases they cause. $\mathrm{Ph}$. D. thesis, Cambridge Univ.

Alfalfa virus N. (Abstract) Phytopathology, 39: 861.

$\mathrm{X}$-disease and other forms of yellow bean mosaic in Western Oregon. Oreg. Agr. Expt. Sta., Sta. Cir. Inform., 379, 6 pp.

Variations in potato calico caused by strains of alfalfa mosaic. (Abstract) Phytopathology, 42: 516-517.

A strain of the alfalfa-mosaic virus causing vine and tuber necrosis in potato. Phytopathology, 40: 973-991.

The inheritance of a yellowspot character in the bean. Jour. Hered., 24: 481-486.

Inheritance of a leaf variegation in the common bean. Jour. Hered., 25: 165-170. 
29. Pierce, W. H. (1934)......... .

30. Pierce, W. H. (1935)..........

31. Price, W. C. (1938)..........

32. Price, W. C. (1940)

33. Quantz, L. (1955).

34. Reddick. D. and Stewart, V. B. (1919)

35. RICHARDS, B. L. (JR.) AND BURKHOLDER, W. H. (1945)

36. SмiтH, K. M. (1937)..........

37. Sмітн, K. M. (1937)..........

38. Sмith, K. M. ANd Bald. J. G (1935)

39. Smith, K. M. and Markham, R. (1944)

40. Smith, K. M. and Markham, R. (1944)

41. SNow, G. F. (1955)

42. Stewart, V. B. and Reddick, D. (1917)

43. Stubis, M. W. (1937)

44. Thomas, H. R. (1951).

45. Thomas, H. R. (1953)

46. Thomas, W. D. AND Graham, R. W. (1951)

47. Thomas, H. R. AND ZaUmeyer, W. J. (1950)

48. Thomas, H. R. AND ZaUmeyer, W. J. (1950)

49. Thomas, H. R. AND Zaumeyer. W. J. (1953)

50. VAN DER WANT, J. P. H. (1948).

51. ZAUMEYER, W. J. (1938)

52. ZAUMEYer, W. J

53. ZAUMEYER, W. J. (1953)

54. ZaumeYer, W. J. AND Fisher, H. H. (1953)

55. ZAUMEYer, W. J. AND HARTER, L. L. (1943)

56. ZAUMEYeR, W. J. AND HARTER, L. L. (1944)
Viroses of the bean. Phytopathology, 24: 87-115.

The identification of certain viruses affecting leguminous plants. Jour. Agr. Res., 51: 1017-1039.

Studies on the virus of tobacco necrosis. Amer. Jour. Bot., 25: $603-612$.

Comparative host range of six plant viruses. Amer. Jour. Bot., 27: 530-541.

Ein Ringfleckenvirus von Buschbohnen. Phytopath. Ztschr., 23: 209-220.

Transmission of the virus of bean mosaic in seed and observations on thermal death-point of seed and virus. Phytopathology, 9: 445-450.

A new mosaic disease of beans. Phytopathology, 33: 1215-1216.

Studies on a virus found in the roots of certain normal-looking plants. Parasitology, 29: 70-85.

Further studies on a virus found in the roots of certain normallooking plants. Parasitology, 29: 86-95.

A description of a necrosis virus disease affecting tobacco and other plants. Parasitology, 27: 231-245.

Two new viruses affecting tobacco and other plants. Phytopathology, 34: 324-329.

A virus disease of lovage (Ligusticum scoticum). Phytopathology, 34: 335-340.

A virus from Gladiolus similar to common bean mosaic. (Abstract) Phytopathology, 45: 696.

Bean mosaic. (Abstract) Phytopathology, 7: 61 .

Certain viroses of the garden pea, Pisum sativum. Phytopathology, 27: 242-266.

Yellow dot, a virus disease of bean. Phytopathology, 41: 967-974.

Isolation of alfalfa mosaic virus strains from field-grown beans. Plant Dis. Reptr., 37: 390-391.

Seed transmission of red-node virus in Pinto beans. Phytopathology, 41: 959-962.

Inheritance of symptom expression of pod mottle virus. Phytopathology, 40: 1007-1010.

Red-node, a virus disease of beans. Phytopathology. 40: 832-846.

A strain of yellow bean mosaic virus producing local lesions on tobacco. Phytopathology, 43: 11-15.

Het stippelstreep van den Boon, (Phaseolus vulgaris), een ziekte veroorzaakt door een virus, dat in de grond overblyft. Tijdschr. over Plantenziekten, 54: 85-90.

A heritable abnormality of beans, resembling mosaic. Phytopathology, 28: 520-522.

The inheritance of a leaf variegation in beans. Jour. Agr. Res., 64: 119-127.

Alfalfa yellow mosaic virus systemically infectious to beans. Phytopathology, 43: $38-42$.

A new necrotic lesion-producing strain of yellow bean mosaic. Phytopathology, 43: 45-49.

Two new virus diseases of beans. Jour. Agric. Res., 67: 305-327.

A severe necrosis caused by bean-mosaic virus 4 on beans. Phytopathology, 34: 510-512. 
57. Zaumeyer, W. J. ANd Thomas, Bean diseases in some of the mountain states in 1947. Plant H. R. (1947) Dis. Rptr. 31: $432-442$.

58. Zaumeyer, W. J. AND Thomas, Pod mottle, a virus disease of beans. Jour. Agr. Res., 77 : H. R. (1948) 81-96.

59. Zaumeyer, W. J. ANd Thomas, Yellow stipple, a virus disease of bean. Phytopathology, 40: H. R. (1950) 847-859.

60. Zaumeyer, W. J. AND WADE, B. L. The relationship of certain legume mosaics to bean. Jour. (1935) Agr. Res., 51: 715-749. 


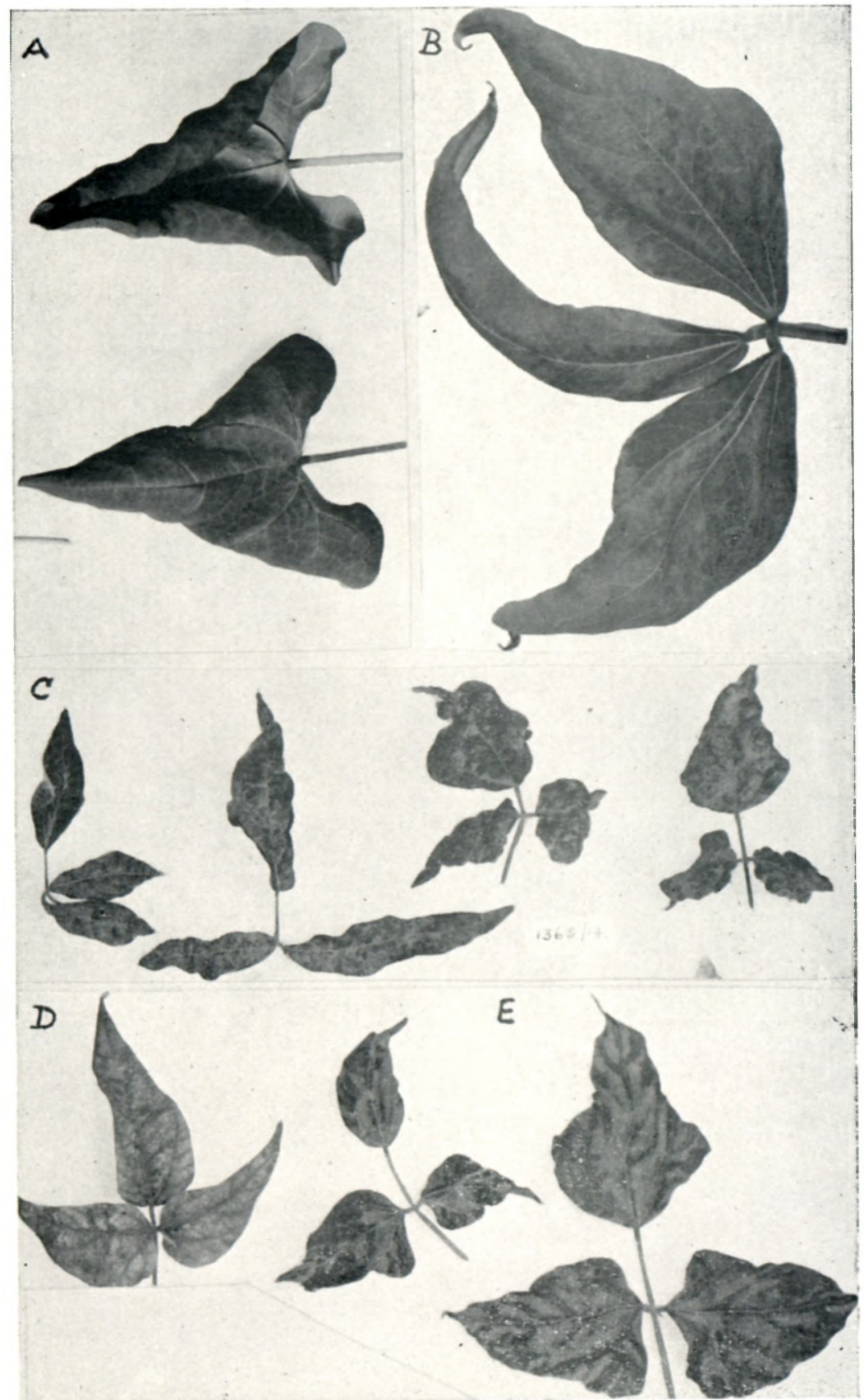

Fig. 1.-Bean Mosaic Virus.

Phaseolus vulgaris vars.

A and B. Canadian Wonder, from infected seed. A. Primary leaves. B. Trifoliate leaves. C. Long Tom. D. Idaho Refugee. E. Kentucky Wonder. C-E. Artificial infection. 


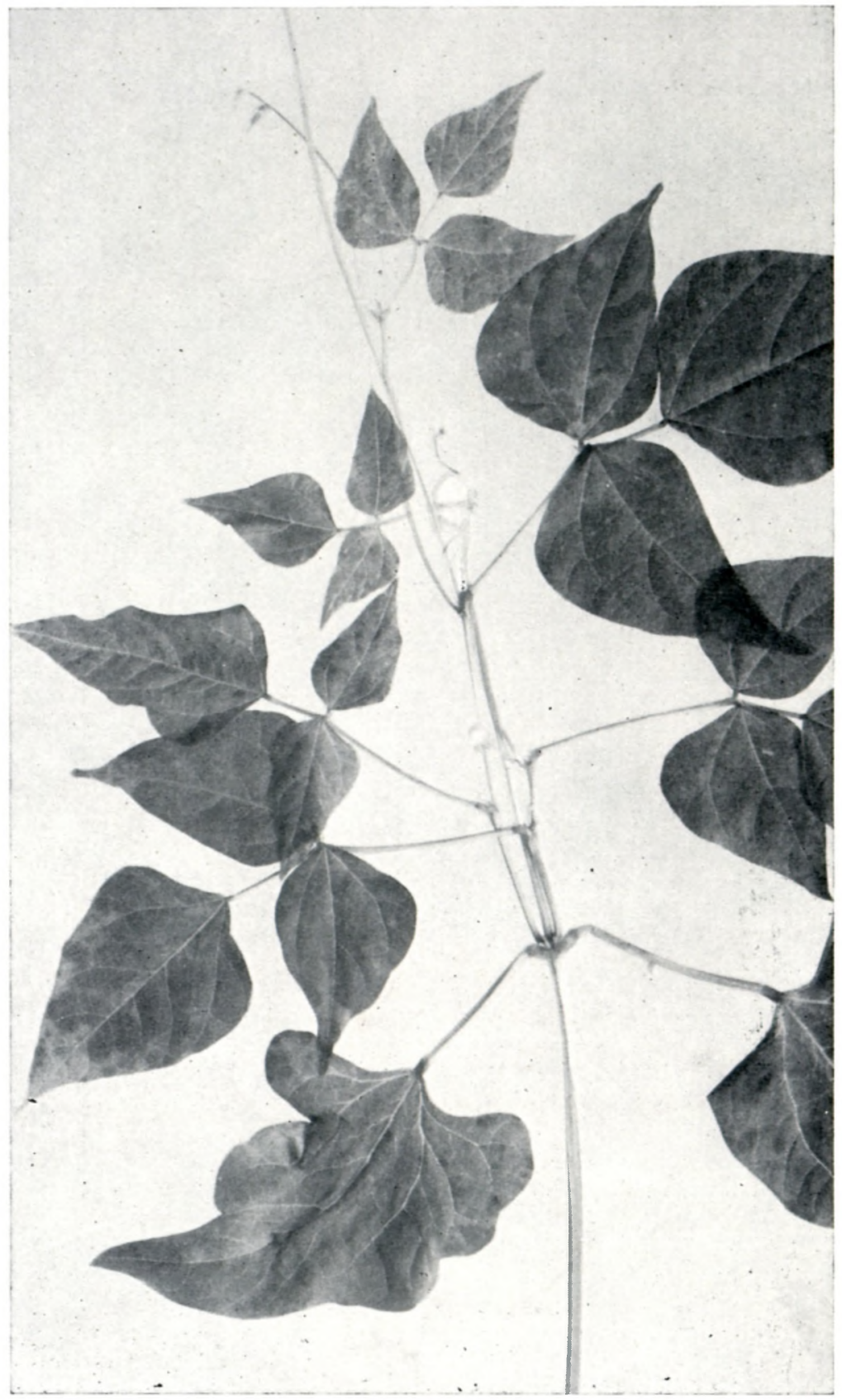

Fig. 2.-Bean Mosaic Virus.

Phaseolus vulgaris var. Haricot, from infected seed. 


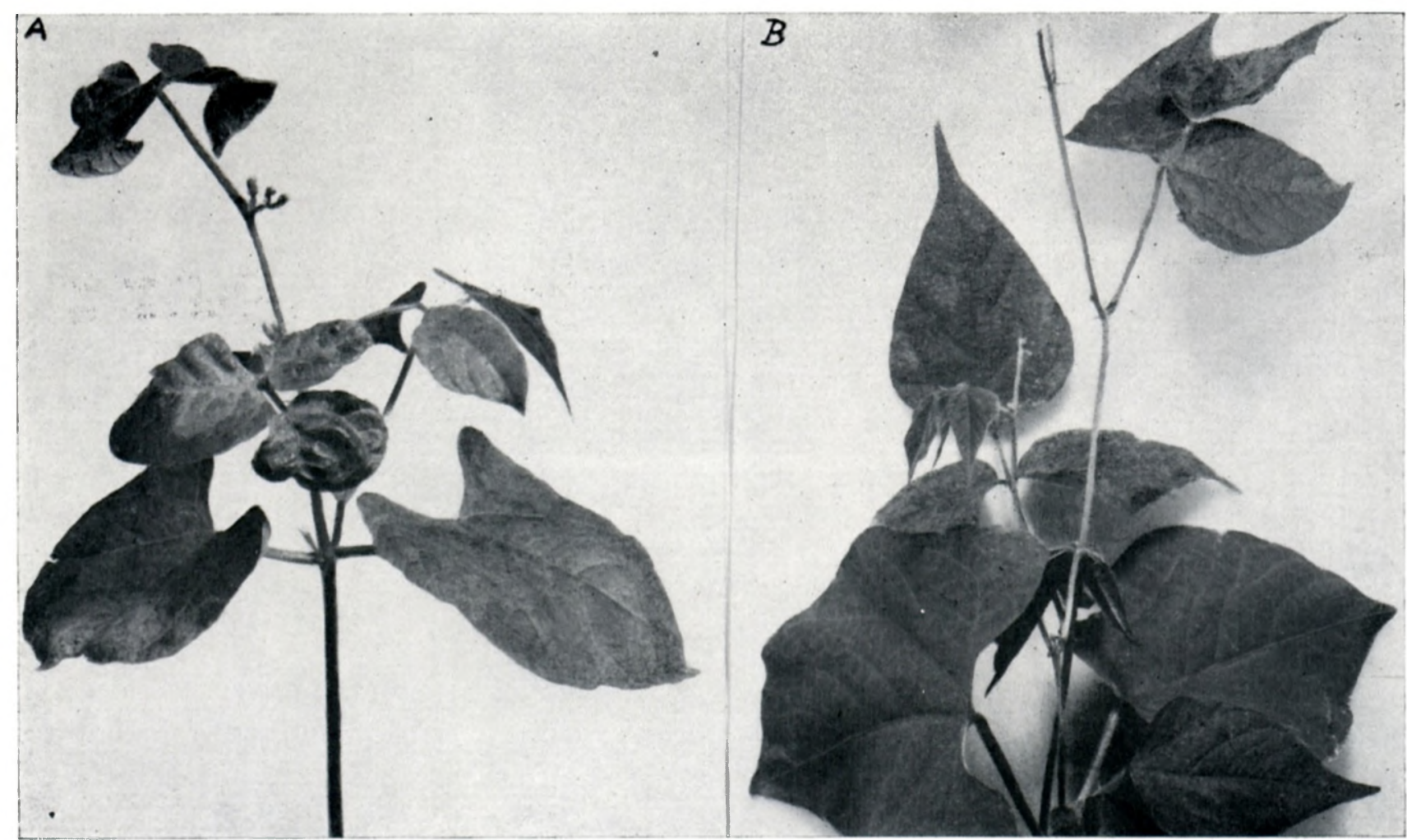

Fig. 3.-3ean Mosaic Virus Strain.

Phaseolus vu'garis var. Canadian Wonder.
A. From infected seed.
B. Artificial infection. 


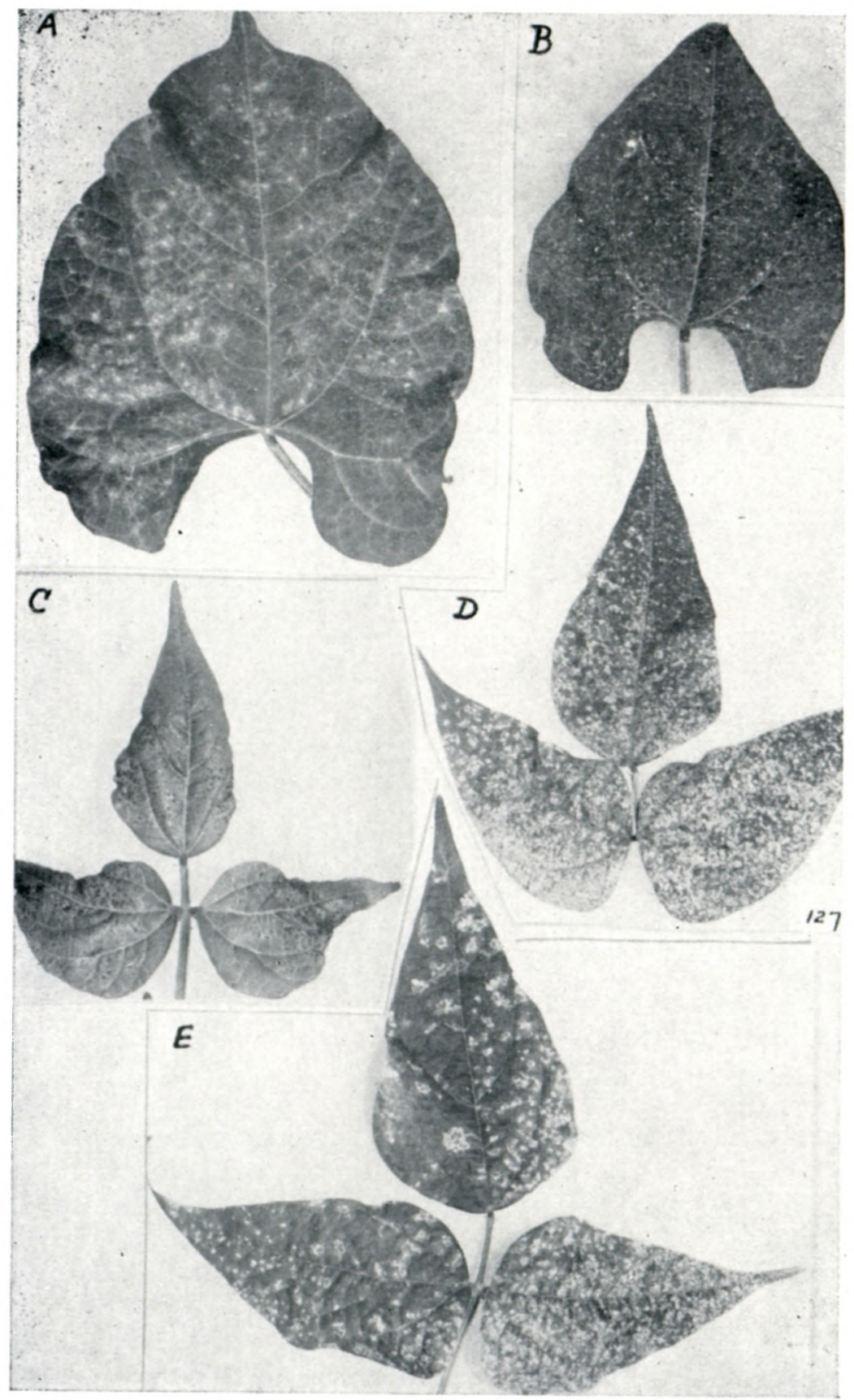

Fig. 4.-Bean Chlorotic Ringspot Virus.

Phaseolus vulgaris.

A. var. Canadian Wonder, local lesions. B. var. Haricot, local lesions. C-E var. Canadian Wonder, systemic symptoms. 


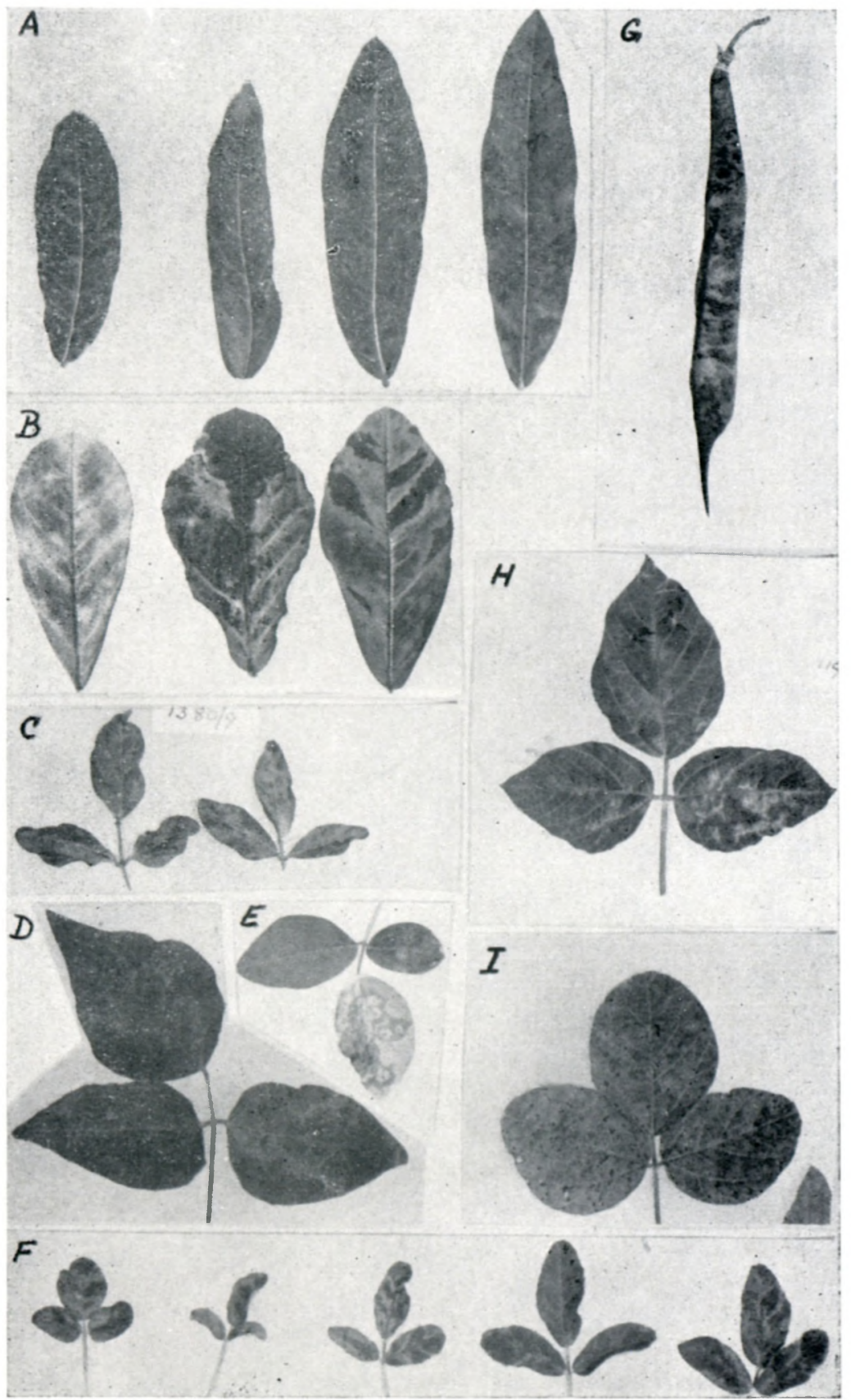

Fig. 5.-Bean Chlorotic Ringspot Virus.

A. Crotalaria juncea. B. C. spectabilis. C. Voandze ia subterranea. D. Phaseolus acutifolius. E. P. lunatus. F. Melilotus officinalis. G. Pod of Phaseolus vulgaris var. Canadian Wonder. $\mathrm{H}$ and I. Glycine max. 

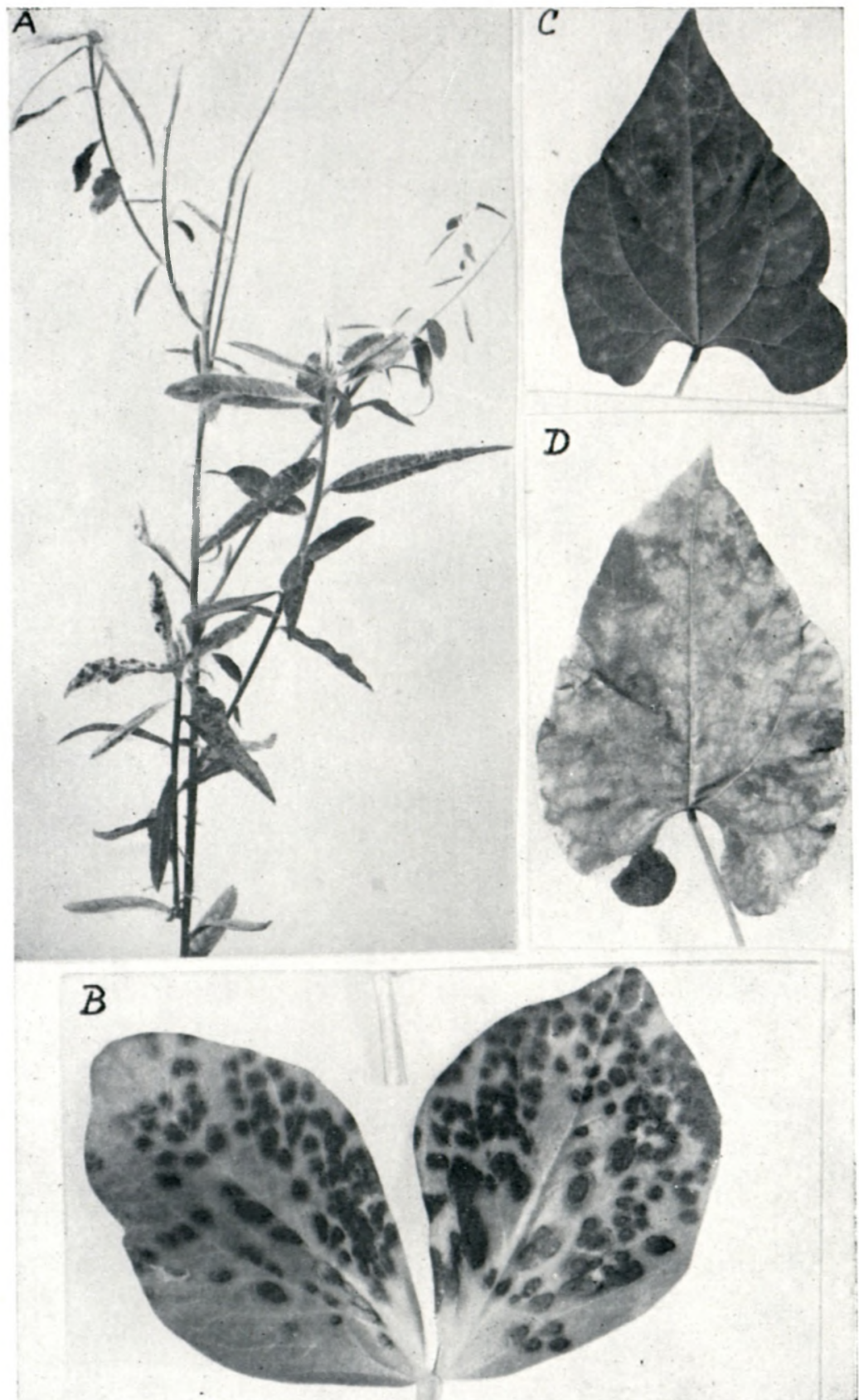

Fig. 6.-Bean Local Chlorosis Virus.

A. Crotalaria juncea. B. Vicia faba. C and D. Phaseolus vulgaris var, Canadian Wonder. 


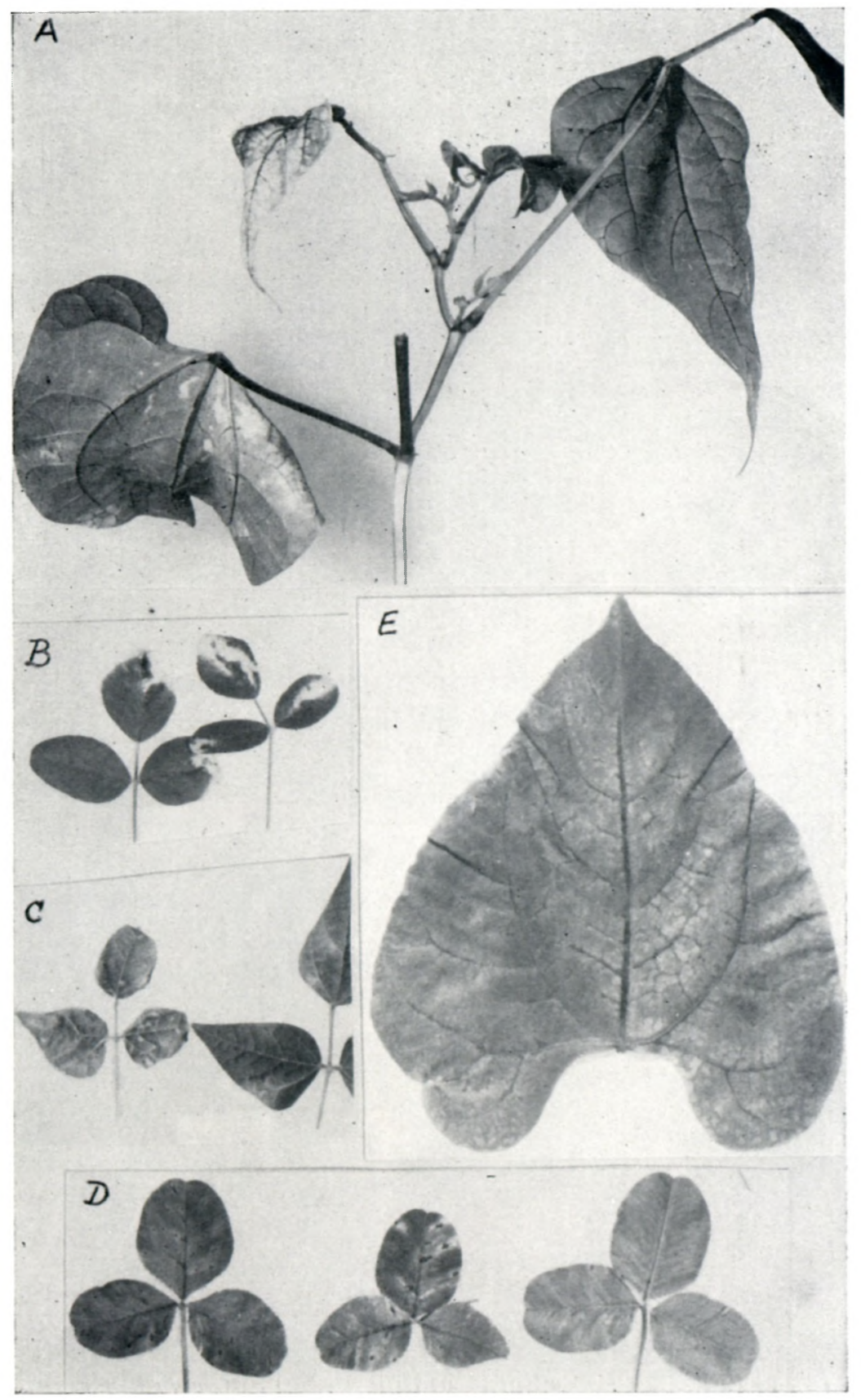

Fig. 7.-BEAN NeCrosis Virus.

A. Phaseolus vulgaris var. Canadian Wonder, systemic necrosis. B. Melilotus officinalis. C. Phaseolus lunatus. D. Trifolium hybridum. E. Phaseolus vulgaris var. Canadian Wonder, local reaction. 


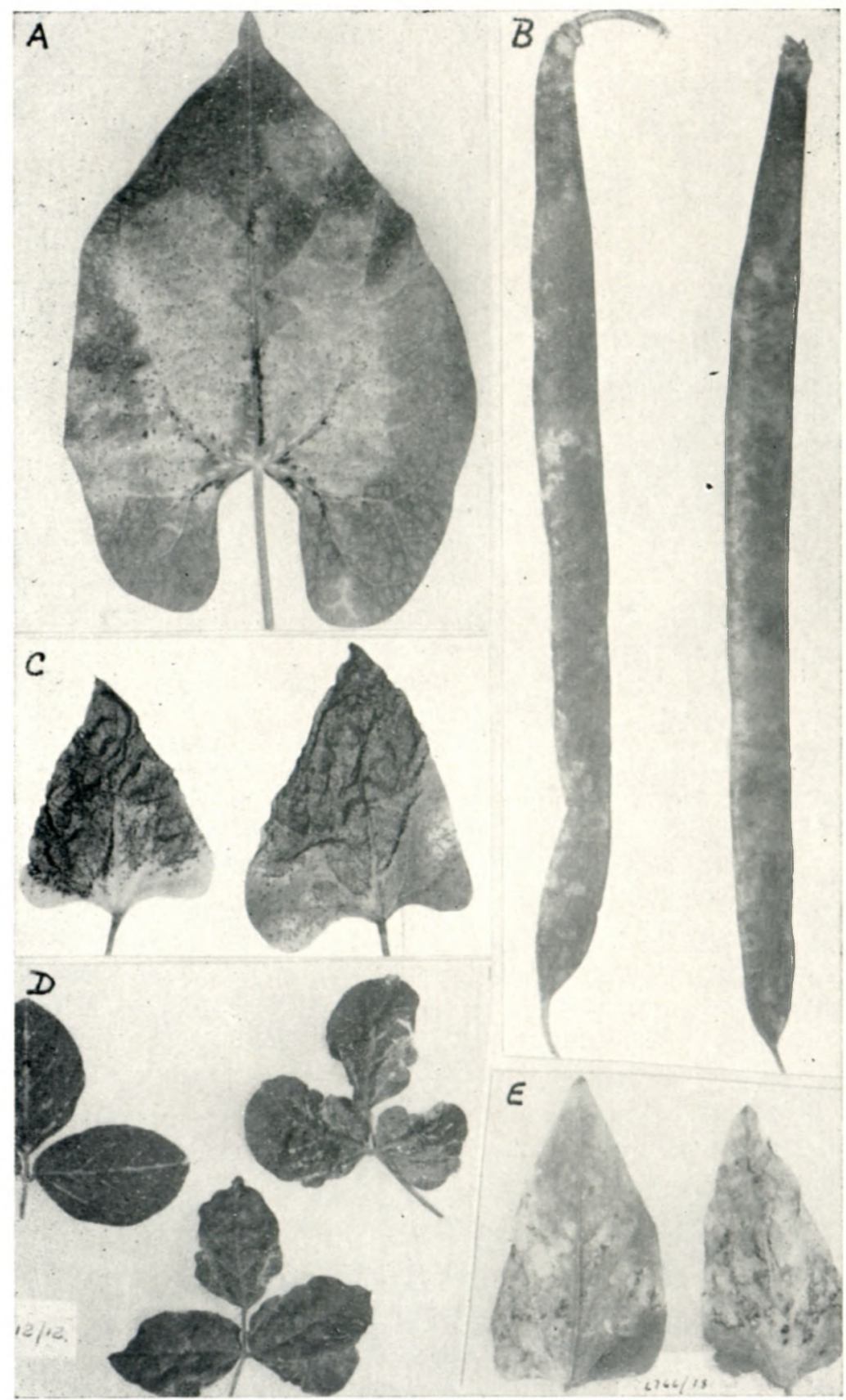

Fig. 8.-Bean Virus Complex.

A-C. Phaseolus vulgaris. A. var. Canadian Wonder, local reaction with the complex. B. Pods of var. Canadian Wonder. C. var. Haricot, local lesions with the bean necrotic speckle virus. D. Glycine max. E. Vigna sesquipedalis. 